TP Periodica Polytechnica Civil Engineering

61 (4), pp. 972-986, 2017

https://doi.org/10.3311/PPci.10688

Creative Commons Attribution (i)

RESEARCH ARTICLE

\section{Comparative Evaluation of Mechanical Properties of Fibre-Reinforced Concrete and Approach to Modelling of Bearing Capacity Ground Slab}

\author{
Oldrich Sucharda ${ }^{*}$, Vlastimil Bilek ${ }^{2}$, Martina Smirakova ${ }^{3}$, \\ Jan Kubosek ${ }^{3}$, Radim Cajka ${ }^{3}$
}

Received 17 March 2017; Accepted 20 April 2017

\begin{abstract}
The use of steel fibre-reinforced concrete is becoming gradually widespread in the engineering design of buildings. Typical cases include concrete foundations or floors. The actual design approach is often different. The proposal significantly encompasses the knowledge and range of the material properties of steel fibre-reinforced concrete. This article presents a comprehensive research programme, which has been focused on extensive laboratory testing, in situ testing and advanced numerical modelling using computing models and nonlinear models of concrete. It aims at a comprehensive description of the material properties of concrete, according to the degree of reinforcement, using 8 types of laboratory tests for description. In total, over 74 specified laboratory tests and four slab tests in situ are carried out. Selected evaluated material properties are also provided for the regression curve according to the degree of reinforcement, 0 to 3\%. Subsequently, the detailed description of steel fibre is used in advanced modelling of tests of concrete slabs in situ. Numerical models simulate the behaviour of the steel fibre-reinforced concrete base structure in the interaction with the subsoil, where the objective was to verify the total carrying capacity of the slab structure.
\end{abstract}

\section{Keywords}

steel fibre-reinforced concrete, slab, mechanical parameters, bending test, finite element method

\section{Introduction}

The use of steel fibre-reinforced concrete for foundations or industrial floors is a typical example. In these cases, the design encompasses many input parameters that significantly influence the results. The basic requirements to optimize the design include in particular a detailed understanding of the properties of the materials used. This is especially important in the case of complex design situations and the use of advanced numerical simulations. In these cases, it is necessary to describe the material properties in a comprehensive manner. A typical case is fibre-reinforced concrete. Fibre-reinforced concrete exists in a number of variants which differ in the materials used and the shape of fibres [1], [2], [3]. Well-known recommendations and standards for the use of steel fibre-reinforced concrete include RILEM [4], DafStB [5] and Model Code 2010 [6]. The properties of steel fibre-reinforced concrete are proven particularly during laboratory tests [7], [8], [9], [10], and [11]. The sensitive material properties of steel fibre include, in particular, the fibre strength of concrete in uniaxial tensile force, fracture energy and the working diagram. A number of authors have devoted themselves to determining the material properties [12], [13], especially tensile strength [14], [15], [16], [17] and [18]. Their testing, however, is difficult and often leads to a variance of measured values [19] and [20]. Common problems include the fact that experimental programmes and testing focus on the properties and testing of the selected material [21]. This hinders the creation of advanced material models for the numerical simulation of the actual behaviour. This is especially the case of nonlinear analysis and the finite element method which requires a detailed computing model and a more comprehensive description of the actual material behaviour. During plane and space problems, a general state of stress emerges. It is also necessary to describe and model the damaged material. This is used to describe concrete fracture mechanics [22]. The juxtaposition of specialized tests often creates questions, thus comprising the research space for a more comprehensive description of the material properties.

With regard to the research project and the goal of a comprehensive description of the material properties of steel 
fibre-reinforced concrete and the subsequent advanced modelling of the nonlinear behaviour of real concrete structures, the experimental programme was split into four parts which differed in degrees of concrete reinforcement from 0 to $3 \%$. The default matrix of steel fibre-reinforced concrete is composed of C25/30 XC2 S3 concrete [6] and steel fibres Dramix 3D 65/60 BG [23].

The experimental programme also included real concrete slabs in situ tests on specialized test equipment [24]. Specifically it was a special kit for testing concrete slabs in interaction with the ground. It allows testing slabs up to $2 \times 2$ metres $\left(4 \mathrm{~m}^{2}\right)$ in size. The slab load is configurable and can go up to 1000 $\mathrm{kN}$. For the case of the experimental programme the slab has the size of $2 \times 2 \mathrm{~m}$, and is loaded at the middle point. The load distributing area has the size of $400 \times 400 \mathrm{~mm}$. The presented test programme was conducted during 2016.

The actual functionality of the test set has been verified by a number of experiments which focused, however, on different research. For example, classic reinforced or pre-stressed concrete slabs and the modelling of subsoil [25] and [26].

\section{Methodology and procedures \\ 2.1 Fibre materials and concrete mix}

Concerning the choice of a fibre for the concrete, there are many possibilities. Fibres differ primarily in the material and shape used. Based on market research and availability, the type of wire chosen was Dramix 3D 65/60 BG [23], which is one of the most frequently found in the Czech Republic at concrete mixing plants and plants manufacturing concrete elements. However, the chosen type is used worldwide (Europe, Brazil, China, Turkey, Indonesia). The basic material properties are summarized in Table 1. The shape of the fibre is shown in Fig. 1.

The selection of the concrete mixture was based on the classes, and the concrete classification according to Eurocodes. With regard to the possibility of workability and representation in the production of concrete mixing plants, concrete $\mathrm{C} 25$ / $30 \mathrm{XC} 2 \mathrm{~S} 3$ was chosen in accordance with the classification [6]. The detailed properties are summarized in Table 2. The maximum grain of the concrete mixture was $16 \mathrm{~mm}$ and the water-cement ratio of 0.6. Portland cement 42.5 MPa (CEM I $42.5 \mathrm{R}$ ) was used for the concrete. The concrete also contains plasticizer Stacheplast. The concrete was produced in the concrete mixing plant in the mixing tower Stetter and subsequently transported by a truck concrete mixer to the place of the preparation of the concrete slabs and samples shown in Fig. 2.

Table 1 Material properties of Dramix fibres 3D 65/60 BG

\begin{tabular}{lc}
\hline Tensile strength: $R_{m, n o m}$ & $1160 \mathrm{~N} / \mathrm{mm} ;$ Tolerances: $\pm 7,5 \%$ Avg \\
\hline Young's Modulus $\left(E_{\text {mod }}\right)$ & $\pm 210000 \mathrm{~N} / \mathrm{mm}$ \\
Amount & 3200 fibres $/ \mathrm{kg}$ \\
Length & $60 \mathrm{~mm}$ \\
Diameter & $0.9 \mathrm{~mm}$ \\
\hline
\end{tabular}

Table 2 Material properties of concrete C25/30 XC2 (S3)

\begin{tabular}{lc}
\hline \multicolumn{1}{c}{$F_{\mathrm{ck}}$} & $25 \mathrm{MPa}$ \\
\hline Consistency & $\mathrm{S} 3$ \\
Maximum grain & $\mathrm{CEM} \mathrm{I}$ \\
Minimum cement content & $300 \mathrm{~kg}$ \\
Water-cement ratio: w/c & 0.6 \\
Aggregates 0/4 (mined) & $870 \mathrm{~kg}$ \\
Aggregates 4/8 (mined) & 150 \\
Aggregates 8/16 (mined) & $820 \mathrm{~kg}$ \\
Water & 1891 \\
Plasticizer & 2.91 \\
\hline
\end{tabular}

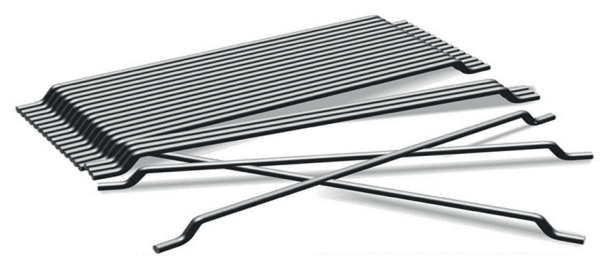

Fig. 1 Fiber Dramix 3D 65/60 BG [23]

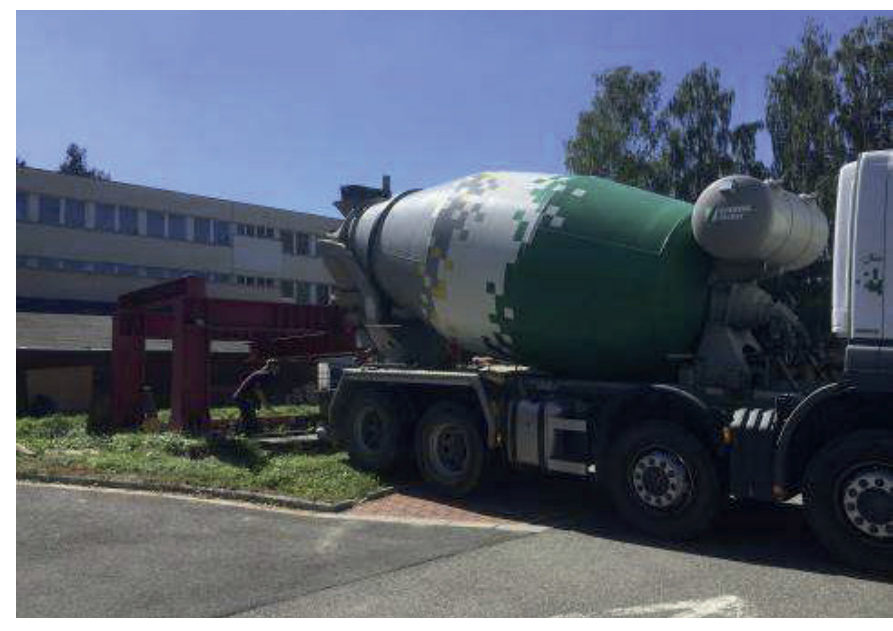

Fig. 2 Truck concrete mixer

\subsection{Laboratory testing schedule}

The experimental programme included the following laboratory tests:

1. TB700(600): Three-point bending test (length $700 \mathrm{~mm}$, span $600 \mathrm{~mm}$, notch $50 \mathrm{~mm}$, cross section $150 \mathrm{~mm} \times 150 \mathrm{~mm}$ ),

2. TB600(500): Three-point bending test (length $700 \mathrm{~mm}$, span $500 \mathrm{~mm}$, cross section $150 \mathrm{~mm} \times 150 \mathrm{~mm}$ ),

3. FB700(600): Four-point bending test - beam (length 700 $\mathrm{mm}$, span $600 \mathrm{~mm}$, section $150 \mathrm{~mm} \times 150 \mathrm{~mm}$ ),

4. FB600(500): Four-point bending test - beam (length 600 $\mathrm{mm}$, span $500 \mathrm{~mm}$, section $150 \mathrm{~mm} \times 150 \mathrm{~mm}$ ),

5. Test of cube strength $(150 \mathrm{~mm} \times 150 \mathrm{~mm} \times 150 \mathrm{~mm})$,

6. Test of split tensile strength $(150 \mathrm{~mm} \times 150 \mathrm{~mm} \times 150 \mathrm{~mm})$,

7. Test of cylinder strength $(150 \mathrm{~mm} \times 300 \mathrm{~mm})$,

8. Three-point bending test (length $480 \mathrm{~mm}$, span $400 \mathrm{~mm}$, notch $27 \mathrm{~mm}$, section $80 \mathrm{~mm} \times 80 \mathrm{~mm}$ ).

The experimental programme shown in Fig. 3. 
Three-point bending test (600)

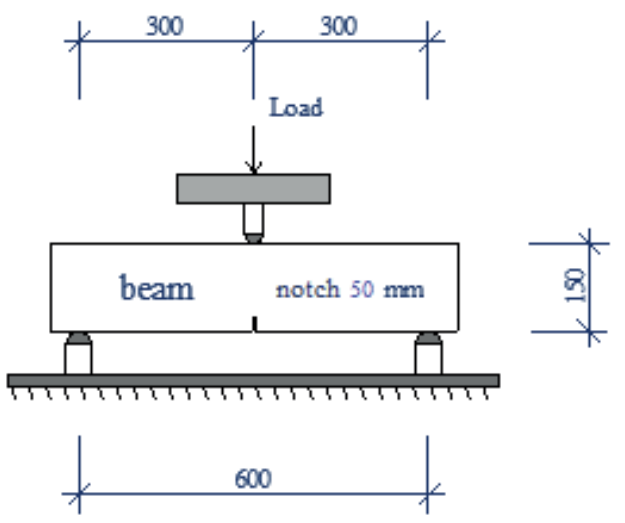

Four-point bending test (600)
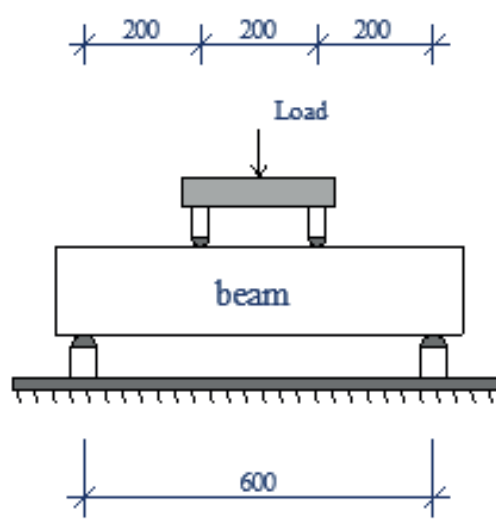

Test of cube strength tensile strength
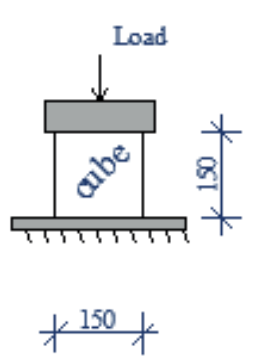

Test of

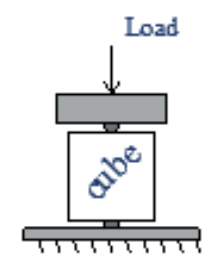

$$
+150 \text { 九 }
$$

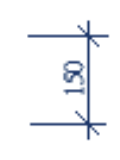

Test of Three-point bending test (500)

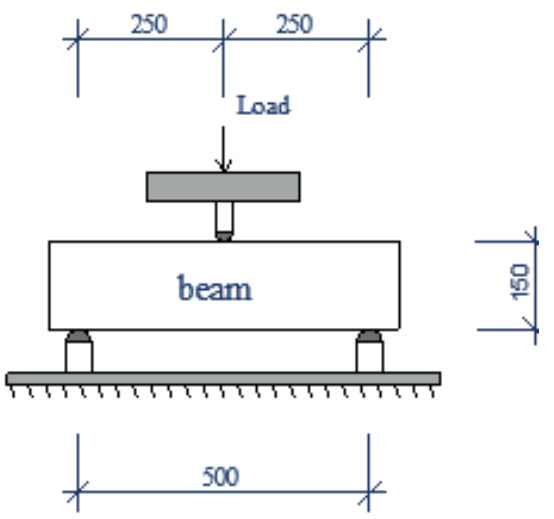

Four-point bending test (500)
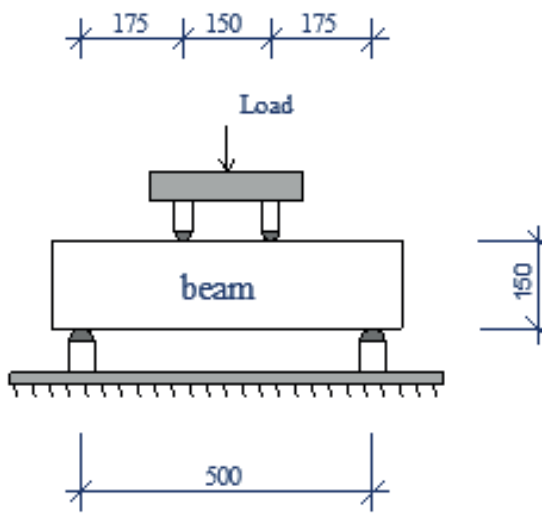

cylinder strength Three-point bending test (480)
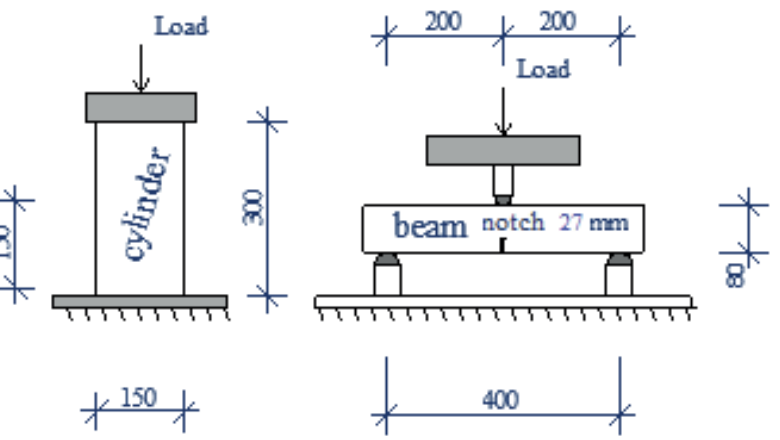

Fig. 3 Testing diagram

\subsection{Ground conditions}

With respect to the in situ concrete test, a verification of field and soil conditions was performed at the site of placement of the concrete slabs. Simultaneously, soil homogenization was also carried out to the depth of $1 \mathrm{~m}$ to achieve appropriate stress-deformational characteristics [26]. Based on the classification, the soil was classified as loamy-clayey. The standard Eurocode 7 was used for the classification. The basic measured values of the soil elasticity module are $E_{\text {def, } 1}=6.8 \mathrm{MPa}$ and $E_{\text {def, } 2}$ $=12.5 \mathrm{MPa}$.

\subsection{Placing the testing concrete}

The concrete mixture was produced in a specialized plant where the fibres had already been put in the concrete mixture. After transporting to the site, the concrete mixture was manually put into the formwork. Continually, the concrete mixture was also sampled for the production of laboratory samples (cubes, cylinders and beams). The concrete mixture was subsequently compacted with surface vibrators. For the verification purposes of the qualitative properties of the concrete, inspection tests of the concrete cube strength were conducted during the curing of the concrete. The evaluation of the laboratory tests was conducted on a set of laboratory presses from the company BETONTECH and DS. For testing the concrete slabs in situ, a measuring set from the company ALBORN was used in combination with a hydraulic frame. The entire set was synchronized during loading. For the purpose of evaluating deformations a total of 16 displacement sensors were used. The location of the track sensors is shown in Fig. 4. 


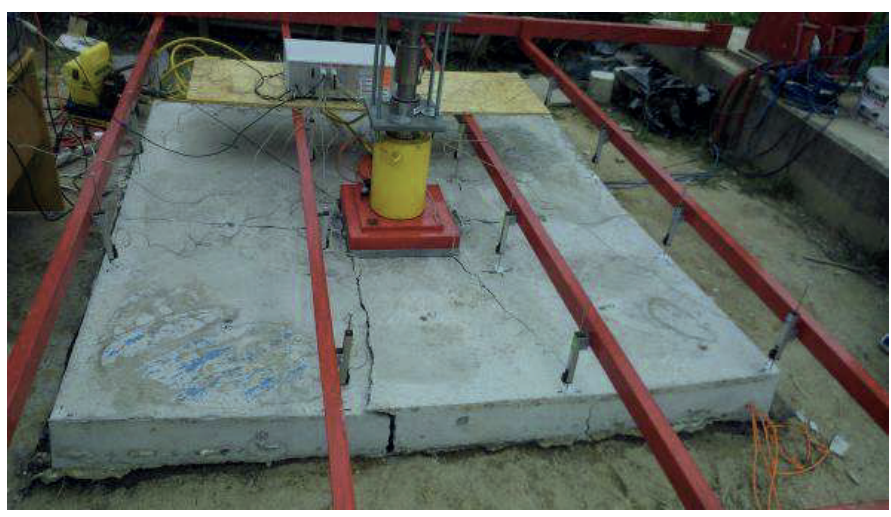

Fig. 4 Concrete slab with ALBORN displacement sensors (slab G02)

\section{Test results}

\subsection{Properties of fresh concrete}

The test programme included eight different configurations of laboratory tests and the testing of concrete slabs. To verify the development of the quality and the strength of the concrete during curing, continuous tests of cube strength were also carried out. The results are summarized in Table 3. The results show a significant increase in the initial strength in the first fourteen days of concrete curing. This is in line with the used cement CEM I 42.5 R.

Table 3 Fresh concrete - paramaters

\begin{tabular}{lccccc}
\hline $\begin{array}{l}\text { Sample } \\
\text { no. }\end{array}$ & $\begin{array}{c}\text { Reinf. } \\
{\left[\mathrm{kg} / \mathrm{m}^{3}\right]}\end{array}$ & $\begin{array}{c}\text { Age tested } \\
{[\text { days }]}\end{array}$ & $\begin{array}{c}\text { Average } \\
\text { density } \\
{\left[\mathrm{kg} / \mathrm{m}^{3}\right]}\end{array}$ & $\begin{array}{c}\text { Average peak } \\
\text { load at failure } \\
{[\mathrm{kN}]}\end{array}$ & $\begin{array}{c}\text { Average } \\
\text { compressive } \\
\text { strength [MPa }]\end{array}$ \\
\hline 1,2 & 0 & 13 & 2284.6 & 492.4 & 22.49 \\
3,4 & 0 & 17 & 2264.4 & 512.1 & 22.91 \\
5,6 & 0 & 20 & 2256.4 & 583.7 & 26.21 \\
1,2 & 25 & 17 & 2319.4 & 726.5 & 32.29 \\
3,4 & 25 & 21 & 2310.1 & 798.4 & 35.49 \\
5,6 & 25 & 24 & 2291.0 & 821.5 & 36.41 \\
1,2 & 50 & 14 & 2308.7 & 593.1 & 26.72 \\
3,4 & 50 & 32 & 2287.4 & 737.9 & 32.25 \\
5,6 & 50 & 42 & 2274.9 & 740.9 & 32.42 \\
1,2 & 75 & 19 & 2293.4 & 595.9 & 27.03 \\
3,4 & 75 & 22 & 2316.6 & 604.7 & 27.07 \\
5,6 & 75 & 25 & 2290.3 & 639.2 & 28.41 \\
\hline
\end{tabular}

Before the laboratory testing, a visual checking of the quality of the samples was also carried out, especially the formation of cracks which had not been detected.

\subsection{Concrete compressive strength}

Concrete compressive strength is one of the basic essential determined characteristics of concrete. The two most common dimension variants of the sample cubes and cylinders were prepared for laboratory tests. For a wider evaluation possibility, 6 cubes and 3 cylinders were produced for each of the four test series. To complement and verify the relation

$$
f_{c k}=(0.8 \approx 0.85) f_{c k, \text { cube }}
$$

the conversion coefficient is determined

$$
\kappa_{c y, c u}=\frac{f_{c k}}{f_{c k, c u b e}}
$$

The test results of compressive strength are summarized in Table 4.

Table 4 Material properties of compression test - results

\begin{tabular}{lcccccc}
\hline Form & $\begin{array}{c}\text { Reinf. } \\
{\left[\mathrm{kg} / \mathrm{m}^{3}\right]}\end{array}$ & Samp. & $\begin{array}{c}\text { Weight } \\
{[\mathrm{kg}]}\end{array}$ & $\begin{array}{c}\text { Average } \\
\text { peak load at } \\
\text { failure }[\mathrm{kN}]\end{array}$ & $\begin{array}{c}\text { Average } \\
\text { compressive } \\
\text { strength }[\mathrm{MPa}]\end{array}$ & $\begin{array}{c}\text { Stand. } \\
\text { dev. }\end{array}$ \\
\hline Cube & 0 & 6 & 7.586 & 562.93 & 25.11 & 0.863 \\
Cube & 25 & 6 & 7.744 & 787.72 & 34.96 & 1.294 \\
Cube & 50 & 6 & 7.854 & 744.63 & 31.65 & 0.853 \\
Cube & 75 & 6 & 7.794 & 625.43 & 27.87 & 0.807 \\
Cyl. & 0 & 3 & 11.586 & 349.33 & 20.03 & 0.336 \\
Cyl. & 25 & 3 & 12.092 & 510.63 & 29.28 & 0.691 \\
Cyl. & 50 & 3 & 11.957 & 440.83 & 25.27 & 1.643 \\
Cyl. & 75 & 3 & 12.289 & 434.13 & 24.90 & 0.822 \\
\hline
\end{tabular}

Table 5 Conversion coefficient

\begin{tabular}{lccccc}
\hline Reinf. $\left[\mathrm{kg} / \mathrm{m}^{3}\right]$ & 0 & 25 & 50 & 75 & Mean \\
\hline $\boldsymbol{\kappa}_{c y, c u}$ & 0.7976 & 0.8375 & 0.7984 & 0.8934 & 0.8317 \\
\hline
\end{tabular}

The results show that in both types of samples (cubes, cylinders), the compressive strength is greater in the samples with fibres than in plain concrete. The increase in compressive strength does not depend explicitly only on the degree of reinforcement. The fibre positioning also has effect in a particular way. This is also evident with regard to the density of concrete and the analysis of the damaged samples. Similar results for the compressive strength of concrete when there is no clear dependency on the degree of reinforcement may be found in [27].

After the evaluation of the compressive strength conversion factor the value of 0.83 was obtained. The actual dispersion of factor values was from 0.79 to 0.89 . The values are summarized in Table 5.

\subsection{Split cube test - Tensile strength}

The actual effect of fibre reinforcement becomes especially evident in the case of tensile strength and flexural tensile strength. There are a number of possibilities to determine the tensile strength. Within the experimental programme, the test of transverse tensile strength on cubes defined in ČSN EN 12390-6 [28] was used.

In the present work, the tensile strength in the transverse direction was calculated as follows:

$$
f_{c t}=\frac{2 P_{\max }}{\pi l d}
$$

where Pmax is the maximum load, 1 is the length of the contact line of the body, and $\mathrm{d}$ is the selected transverse dimension of the body.

The final evaluation of the tests in transverse strength is given in Table 6. 
Table 6 Split cube test - results

\begin{tabular}{lcccccc}
\hline Form & Reinf. & Sample & Weight & $\begin{array}{c}\text { Average peak } \\
\text { load at failure } \\
{[\mathrm{kN}]}\end{array}$ & $\begin{array}{c}\text { Average ten- } \\
\text { sile strength } \\
{[\mathrm{MPa}]}\end{array}$ & Stand \\
\hline Cube & 0 & 6 & 7.518 & 74.03 & 2.10 & 0.280 \\
Cube & 25 & 6 & 7.818 & 101.54 & 2.96 & 0.204 \\
Cube & 50 & 6 & 7.788 & 110.0 & 3.12 & 0.191 \\
Cube & 75 & 6 & 7.794 & 111.2 & 3.17 & 0.541 \\
\hline
\end{tabular}

The results of the laboratory tests show an obvious effect of the fibres on tensile strength. The tensile strength is significantly higher, typically by about $1 \mathrm{MPa}$. This is approximately $50 \%$. The actual difference in tensile strength in the reinforced samples is, however, very small. The values of tensile strength range from 2.96 to $3.17 \mathrm{MPa}$.

\subsection{Flexural tensile strength}

The most important parameters determined for steel fibrereinforced concrete include flexural tensile strength [29], [30] and [31]. The flexural tensile strength was determined on two types of beams. These were large beams with the cross section of $150 \times 150 \mathrm{~mm}$, and small ones with the cross section of $80 \times 80 \mathrm{~mm}$ in Fig. 5. The flexural tensile strength specified for the selected type of a notched beam was determined according to other researchers [31] and [32]. In the present work it was calculated using the following equation:

$$
\sigma_{c x}=\frac{3 P_{\max } L}{2 b\left(h-a_{0}\right)^{2}}
$$

where $P_{\max }$ is the maximum load; $L, b$ and $h$ are the span, width and depth of the beam; $a_{0}$ is the notch depth.

In the test results of the notched beams in Table 7 and 8 , there is an evident significant influence of fibres in both variants on the maximum flexural tensile strength.

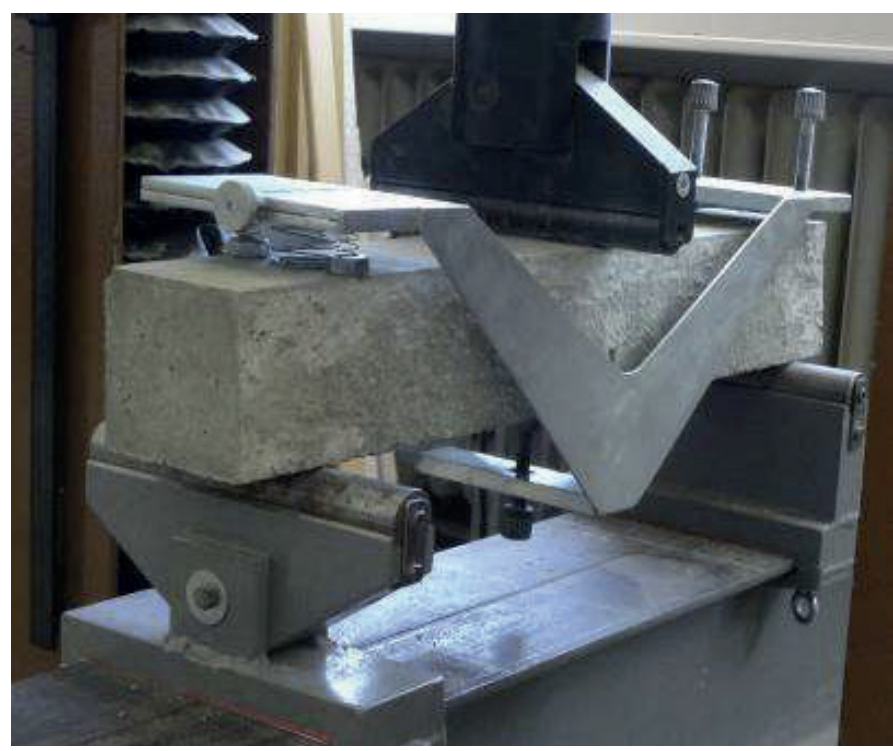

Fig. 5 Three-point bending test (480)
The beams with the cross section of $150 \times 150 \mathrm{~mm}$ have maximum values of flexural tensile strength ranging from $1.935 \mathrm{MPa}$ to $3.251 \mathrm{MPa}$. In smaller beams with the $80 \times 80$ $\mathrm{mm}$ cross section, the value is 19.80 to $25.81 \mathrm{MPa}$.

In both tests, it was determined that the greater the content of fibres, the higher the flexural tensile strength was achieved.

Table 7 Flexural tensile strength; beam - cross $80 \times 80 \mathrm{~mm}$

\begin{tabular}{lcccc}
\hline Reinf. & Sample & Weight & $\begin{array}{c}\text { Average peak load } \\
\text { at failure }[\mathrm{kN}]\end{array}$ & $\begin{array}{c}\text { Average tensile } \\
\text { strength [MPa] }\end{array}$ \\
\hline 0 & 6 & 7.171 & 7.415 & 19.80 \\
25 & 6 & 7.334 & 8.210 & 21.92 \\
50 & 3 & 7.407 & 8.376 & 22.37 \\
75 & 3 & 7.323 & 9.666 & 25.81 \\
\hline
\end{tabular}

Table 8 Flexural tensile strength; beam - cross 150x150 mm

\begin{tabular}{lccccc}
\hline Reinf. & Sample & Weight & $\begin{array}{c}\text { Average peak } \\
\text { load at failure } \\
{[\mathrm{kN}]}\end{array}$ & $\begin{array}{c}\text { Average ten- } \\
\text { sile strength } \\
{[\mathrm{MPa}]}\end{array}$ & $\begin{array}{c}\text { Peak load at } \\
\text { failure }[\mathrm{kN}]\end{array}$ \\
\hline 0 & 2 & 35.711 & 5.040 & 1.935 & $4.99 ; 5.09$ \\
25 & 2 & 36.872 & 6.675 & 2.563 & $6.8 ; 6.55$ \\
50 & 2 & 36.389 & 6.985 & 2.682 & $6.88 ; 7.09$ \\
75 & 2 & 36.888 & 8.465 & 3.251 & $8.81 ; 8.12$ \\
\hline
\end{tabular}

\subsection{Flexural tests results}

The important results of the laboratory tests include the results of the load displacement (LD) diagrams of the large beams. From these records it is possible to evaluate other important parameters necessary for the design and analysis of steel fibre-reinforced concrete structures. Within the experimental programme, especially the maximum load strength and the fracture energy were evaluated. The fracture energy is one of the basic parameters of advanced analyses which describe the capability of concrete to withstand the load, depending on its strain deformation characteristics. The area of the determination of the perameters of fracture mechanics encompasses the full range of approaches. The fracture energy is defined as the amount of energy necessary to create a crack of the unit surface area projected in a plane parallel to the crack direction [10], [33], [34] and [35]. The calculation can be described as follows:

$$
G_{F}=\frac{W_{0}+m g \delta}{b\left(h-a_{0}\right)}
$$

where $W_{0}$ - area under the load-deflection curve, $m$ - mass of the specimen, $g$ - gravity, $b, h$ - beam thickness and depth, $\delta$ - deflection at final fracture, $a_{0}$ - notch depth.

Ideally, the fracture energy is calculated for the complete process of loading. It is typical e.g. for plain concrete. But in the case of steel fibre-reinforced concrete, the post-peak phase of loading is often limited by the possibilities of measurement. During the advanced post-peak phase of load, the residual load carrying capacity usually remains for a long time. With regard to this, in the case of steel fibre-reinforced concrete only a 
certain area is often defined. In the case of recommendation TDM-162 [8] it is $5 \mathrm{~mm}$. The load and measuring sets used enabled a measuring deflection up to $8 \mathrm{~mm}$. The actual evaluation of the fracture energy is therefore made for both deformation values, and a ratio coefficient is also established

$$
h_{G F}=\frac{G_{F(8)}}{G_{F(5)}}
$$

Bending tests included four series. Each series consisted of four different reinforced beams. Each reinforced grade has two beams. The final LD diagrams for the three-point bending test with $150 \times 150 \times 700 \mathrm{~mm}$ beams are shown in Fig. 6. The beams had a span of $600 \mathrm{~mm}$. The notch depth was 50 $\mathrm{mm}$. The final calculated values of the fracture energy are summarized in Table 9.

Table 9 Fracture energy [N/m]: TB700(600) - mean value

\begin{tabular}{lcccc}
\hline Reinforment $\mathrm{kg} / \mathrm{m}$ & 75 & 50 & 25 & 0 \\
\hline$G_{\mathrm{f}(5)}$ & 2707 & 2170 & 1722 & 160 \\
$G_{\mathrm{f}(8)}$ & 3978 & 3163 & 2617 & - \\
$G_{\mathrm{f}(8)} / G_{\mathrm{f}(5)}$ & 1.47 & 1.46 & 1.52 & \\
\hline
\end{tabular}

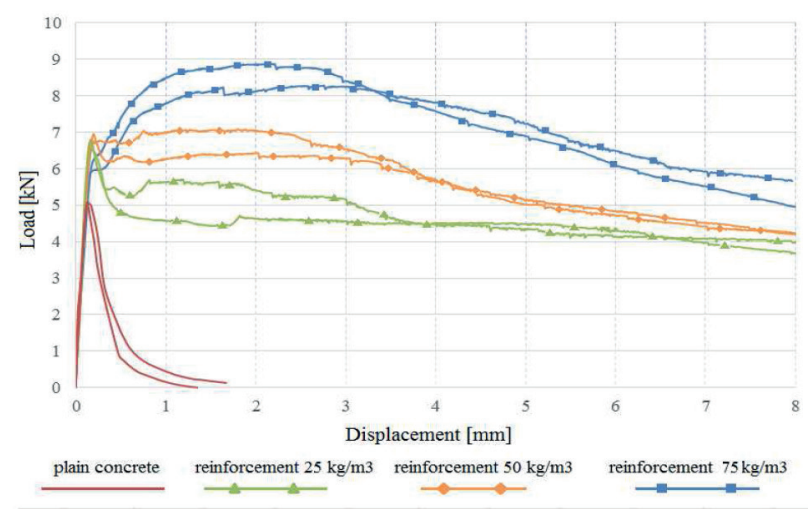

Fig. 6 LD diagrams - Test TB700(600)

The curve of LD diagrams distinguishes the beams very well according to the degree of reinforcement.

The fibre-reinforced beams show that the pre-peak loading phase and the maximum load are very similar. In the case of the post-peak phase of loading, the sequence of the LD diagrams for each degree of beam reinforcement differs significantly. The values of fracture energy $G_{\mathrm{f}(5)}$ for fiber concrete range from $1646 \mathrm{~N} / \mathrm{m}$ to $2748 \mathrm{~N} / \mathrm{m}$.

Another type of beam had the dimensions of $150 \times 150 \times$ $600 \mathrm{~mm}$. The beam was without a notch and again 8 tests were conducted. A three-point bending test was conducted. The beam span was $500 \mathrm{~mm}$. In comparison with the previous type of test, the fracture localization was not made, ie. in the case of the notch, the fracture place was determined before the test. The final load diagrams are shown in Fig. 7.

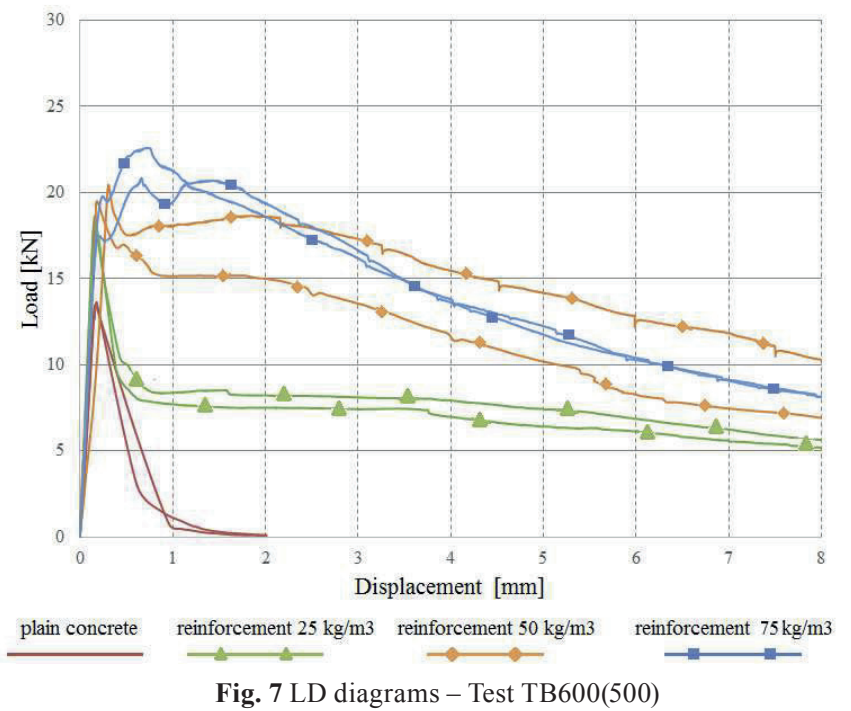

The final calculated values of the fracture energy are summarized in Table 10. The values of fracture energy $G_{\mathrm{f}(5)}$ range from $1808 \mathrm{~N} / \mathrm{m}$ to $3803 \mathrm{~N} / \mathrm{m}$.

Table 10 Fracture energy [N/m]: TB600(500) - mean value

\begin{tabular}{lcccc}
\hline Reinforment $\mathrm{kg} / \mathrm{m}$ & 75 & 50 & 25 & 0 \\
\hline$G_{\mathrm{f}(5)}$ & 3796 & 3464 & 1894 & 321 \\
$G_{\mathrm{f}(8)}$ & 5153 & 4846 & 2766 & - \\
$G_{\mathrm{f}(8)} / G_{\mathrm{f}(5)}$ & 1.36 & 1.39 & 1.46 & \\
\hline
\end{tabular}

Again, beams $150 \times 150 \times 700 \mathrm{~mm}$ and $150 \times 150 \times 600 \mathrm{~mm}$ were used. In the case of the longer beams the beam span was $600 \mathrm{~mm}$. Load forces act in thirds of the span. The final LD diagrams are shown in Fig. 8 and the fracture energy, in Table 11.

Table 11 Fracture energy [N/m]: FB700(600) - mean value

\begin{tabular}{lcccc}
\hline Reinforment $\mathrm{kg} / \mathrm{m}$ & 75 & 50 & 25 & 0 \\
\hline$G_{\mathrm{f}(5)}$ & 4362 & 3015 & 2439 & 207 \\
$G_{\mathrm{f}(8)}$ & 5869 & 3965 & 3558 & - \\
$G_{\mathrm{f}(8)} / G_{\mathrm{f}(5)}$ & 1.34 & 1.34 & 1.46 & \\
\hline
\end{tabular}

In the case of this test it is again possible to clearly distinguish the LD diagrams of the beams according to the degree of reinforcement.

Only in the case of one beam with the reinforcement of $2 \%$ were better results achieved than with beams with the reinforcement of $3 \%$ in the post-peak phase of loading. The values of fracture energy $G_{\mathrm{f}(5)}$ range from $2332 \mathrm{~N} / \mathrm{m}$ to $5178 \mathrm{~N} / \mathrm{m}$. The experimental programme continued with the four-point bending tests. In this type of testing, the possible area of crack origin localization is wider. Typically, it is between the applied forces. 


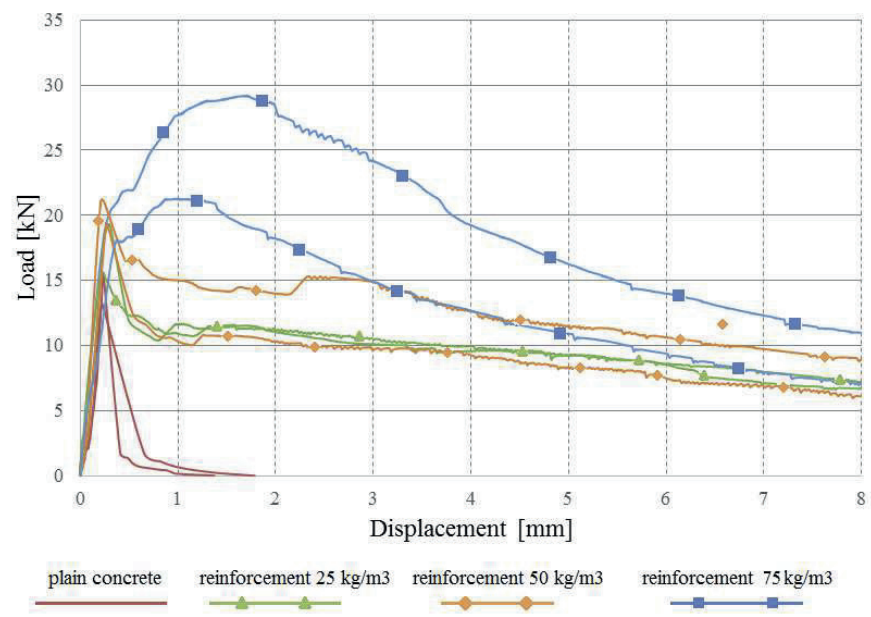

Fig. 8 LD diagrams - Test FB700(600)

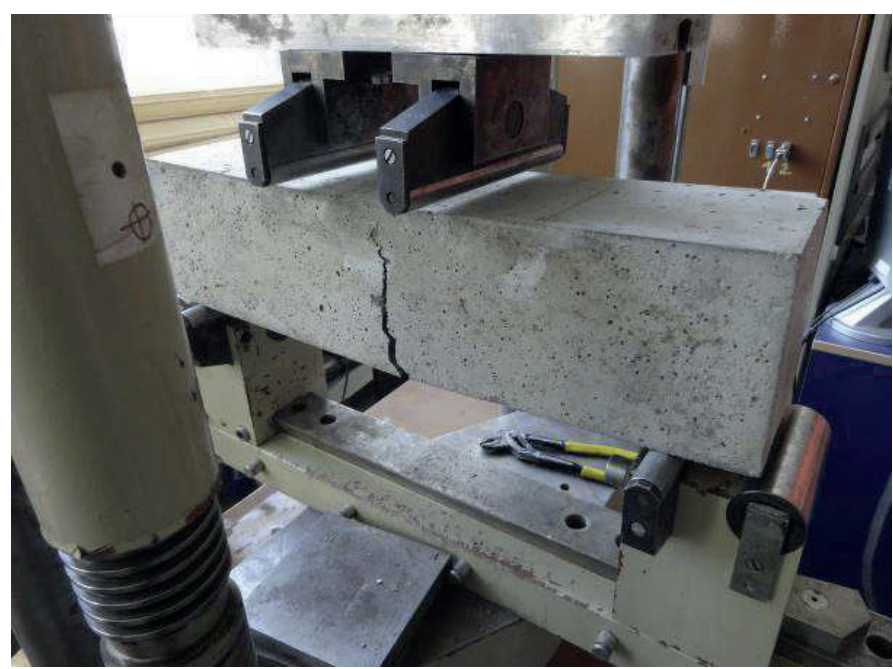

Fig. 9 Four-point bending test - beam $150 \times 150 \times 600$, span $500 \mathrm{~mm}$

The last variant of four-point bending tests in Fig. 9 are beams $600 \mathrm{~mm}$ in length. The beam span in this test is $500 \mathrm{~mm}$ in this case. The distance of the pair of load forces is $150 \mathrm{~mm}$. The final LD diagrams are shown in Fig. 10 and the fracture energy values are in Table 12.

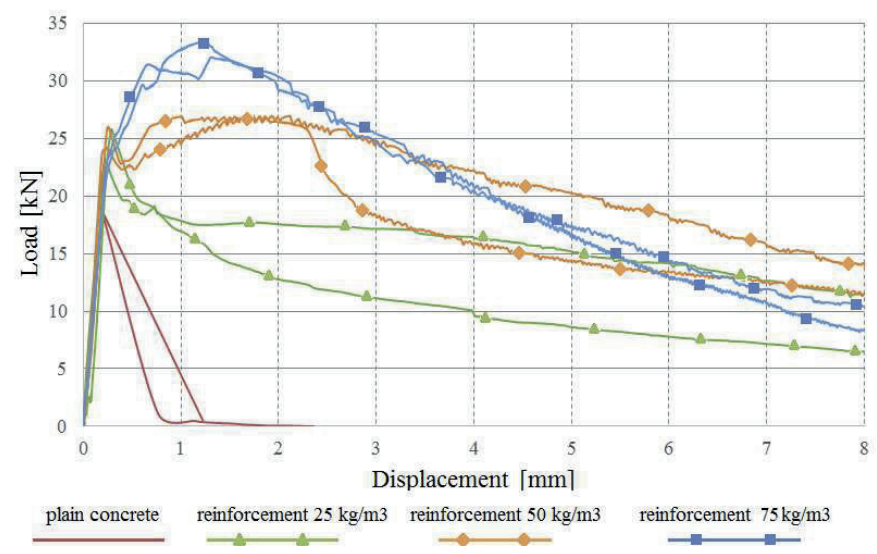

Fig. 10 LD diagrams - Test FB600(500)
Table 12 Fracture energy [N/m]: FB600(500) - mean value

\begin{tabular}{lcccc}
\hline Reinforment $\mathrm{kg} / \mathrm{m}$ & 75 & 50 & 25 & 0 \\
\hline$G_{\mathrm{f}(5)}$ & 5641 & 4977 & 3400 & 471 \\
$G_{\mathrm{f}(8)}$ & 7373 & 7021 & 4824 & - \\
$G_{\mathrm{f}(8)} / G_{\mathrm{f}(5)}$ & 1.31 & 1.41 & 1.42 & \\
\hline
\end{tabular}

The fracture energy values from the tests for $G_{\mathrm{f}(5)}$ range from $2913 \mathrm{~N} / \mathrm{m}$ to $5666 \mathrm{~N} / \mathrm{m}$.

\subsection{Results of LD diagrams}

A comprehensive set of laboratory bending tests enables a broader evaluation of LD diagrams and a determination of regression curves for the maximum load and the fracture energy. The aggregate values of the maximum load carrying capacity for bending tests are given in Table 13.

Table 13 Maximum load for bending test - mean value

\begin{tabular}{lccccc}
\hline \multirow{2}{*}{ Bending } & Span & \multicolumn{5}{c}{ Reinforcement kg/m } \\
\hline 3 & & 0 & 25 & 50 & 75 \\
4 & 500 & 13.54 & 18.40 & 19.98 & 21.71 \\
3 & 500 & 18.35 & 24.51 & 26.68 & 32.53 \\
4 & 600 & 5.4 & 6.68 & 6.99 & 8.47 \\
\hline
\end{tabular}

For the determination of regression curves it is evident that the maximum load and the fracture energy depend on the degree of reinforcement. For the determination of regression curves the linear relationship is assumed. In the case of the maximum load for a four-point test of a notched beam it is possible to write a regressive curve:

$$
F_{\max , 500(4)}=0.1867 x+F_{\max , 500(4),(x=0)}\left(R^{2}=0.9682\right)
$$

and for the beam without notch:

$$
F_{\max , 600(4)}=0.1367 x+F_{\max , 600(4),(x=0)}\left(R^{2}=0.9807\right)
$$

where $F_{\max }$ is the maximum force in the beam without reinforcement and $x$ is the mass of fibre per $\mathrm{m}^{3}$.

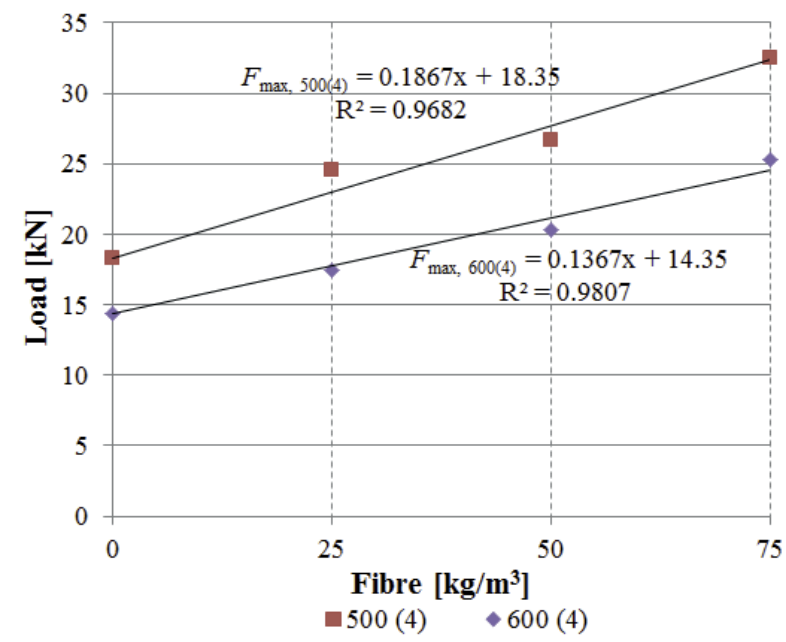

Fig. 11 Maximum load with respect to the fibre volume ratio (four-point bending test) 
The results are graphically shown in Fig. 11. In both cases the correlation coefficient is greater than 0.96 .

Based on these test results it is also possible to predict the fracture energy in Fig. 12. The following functions can be written for the notched beam:

$$
G_{F, 500(4)}=78.431 x+G_{F, 500(4),(x=0)}\left(R^{2}=0.8876\right)
$$

and for the beam without a notch:

$$
G_{F, 600(4)}=58.037 x+G_{F, 600(4),(x=0)}\left(R^{2}=0.9268\right)
$$

Similarly, it is also possible to determine the regression curves in Fig. 13 for the maximum load capacity in the threepoint bending test.

The regression curves determined for the notched beam are:

$$
F_{\max , 500(3)}=0.1207 x+F_{\max , 500(3),(x=0)}\left(R^{2}=0.8830\right)
$$

and for the beam without notch:

$$
F_{\max , 600(3)}=0.0391 x+F_{\max , 600(3),(x=0)}\left(R^{2}=0.9489\right)
$$

Based on these test results it is also possible to predict fracture energy in Fig. 14.

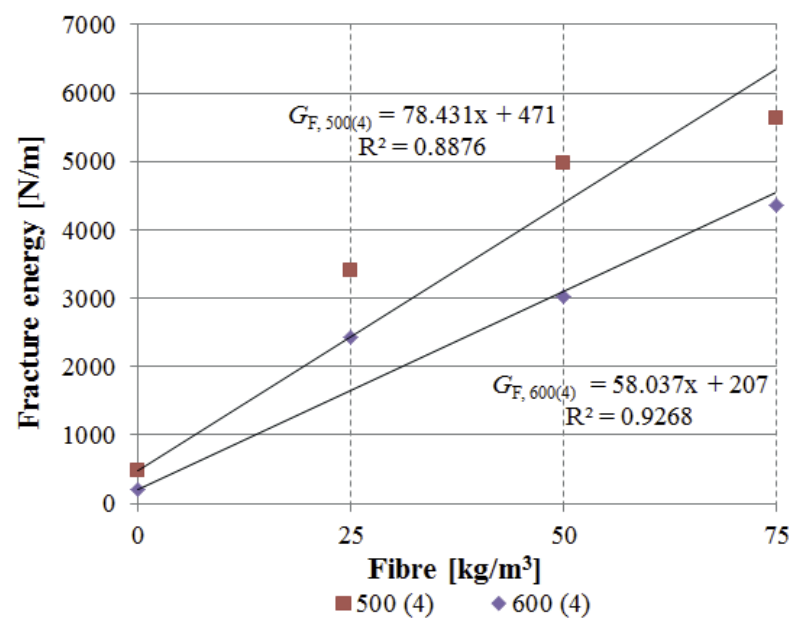

Fig. 12 Fracture energy with respect to the fibre volume ratio (four-point bending test)

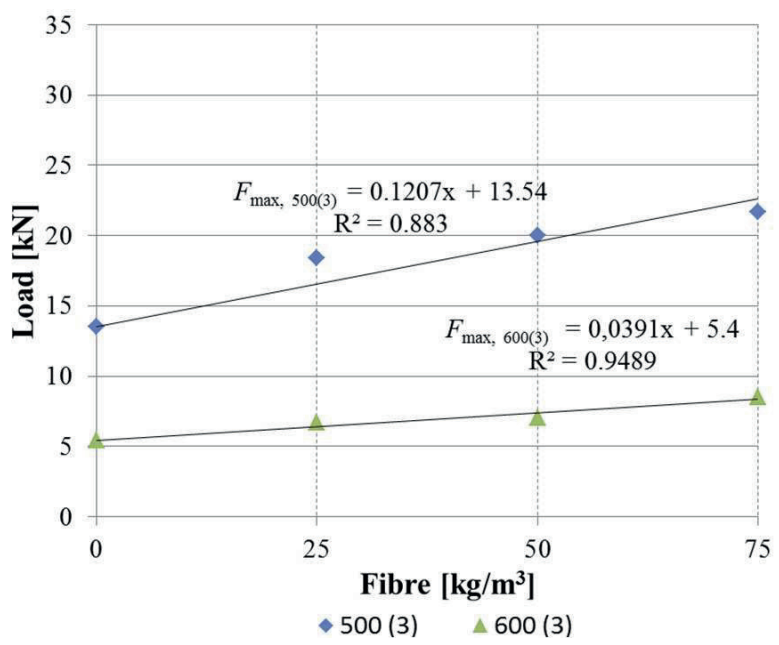

Fig. 13 Maximum load with respect to the fibre volume ratio (three-point bending test)

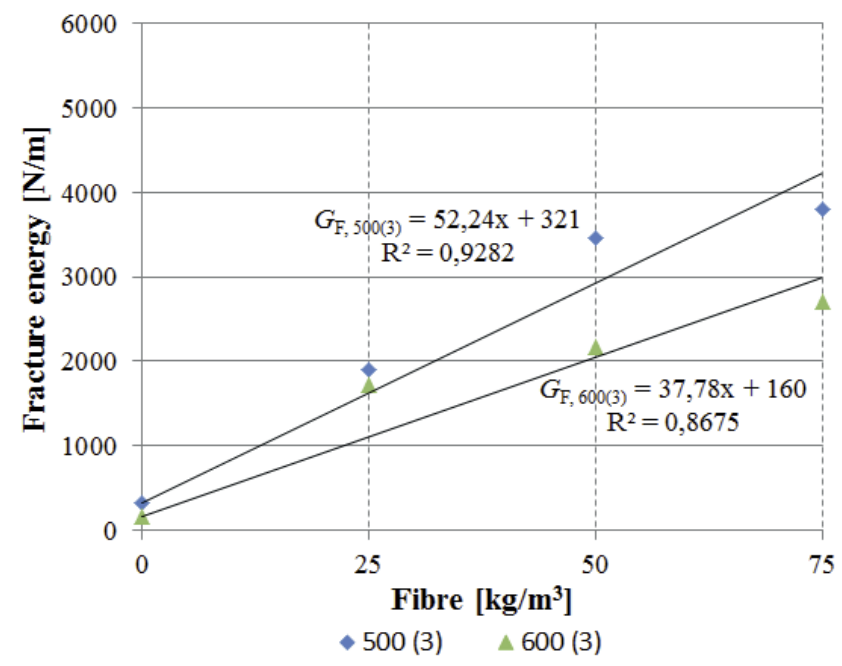

Fig. 14 Fracture energy with respect to the fibre volume ratio (three-point bending test)

The following functions can be written as:

$$
G_{F, 500(3)}=52.24 x+G_{F, 500(3),(x=0)}\left(R^{2}=0.9282\right)
$$

and for the beam without a notch:

$$
G_{F, 600(3)}=37.78 x+G_{F, 600(3),(x=0)}\left(R^{2}=0.8675\right)
$$

\subsection{Slab tests}

In parallel with the laboratory tests the testing of concrete slabs was carried out at a specialized facility. As previously stated, before the testing of the concrete slabs a verification of strain-deformation properties of the soil was performed. The aim of the concrete slab tests was mainly to determine the load curve for the case of a real structure, a maximum load and the method of construction collapse.

During the load tests, in particular, a measurement of the vertical deformation was carried out by means of a set of 16 sensors and the load force was carried out by a hydraulic jack. The location of the sensors for each slab is shown in Fig. 15.

The basic size of the concrete slab was $2000 \times 2000 \mathrm{~mm}$. The slab nominal thickness was $150 \mathrm{~mm}$. The load spreading area has the dimensions of $400 \times 400 \mathrm{~mm}$. The loading of slabs proceeded in steps. One load step lasted 30 minutes. The load increment differed depending on the expected maximum load and the maximum length of 7 hours of testing. The length of the load step of 30 minutes was selected considering the load transfer increments through a hydraulic jack.

The first slab G01 was made from plain concrete. According to estimates, the lowest bearing capacity was reached in the case of slabs without reinforcement.

The test and records show that the first substantial change of stiffness and the first crack opening at the bottom surface occurred with the load of $67.5 \mathrm{kN}$ after 1.5 hours. Furthermore, there was a gradual increase in load and crack growth from the bottom surface upwards. 


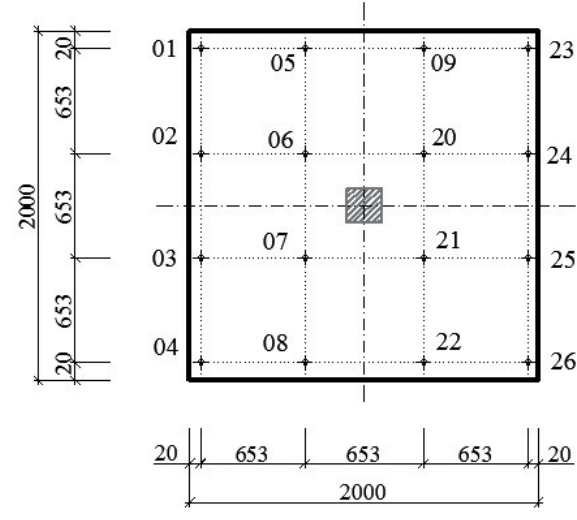

G03_23.8.2016

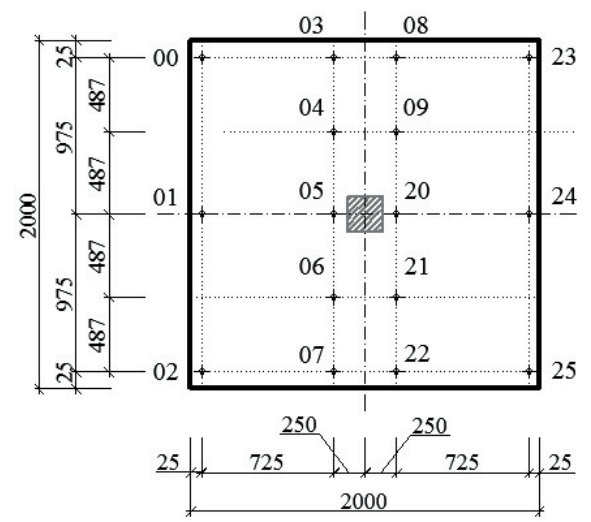

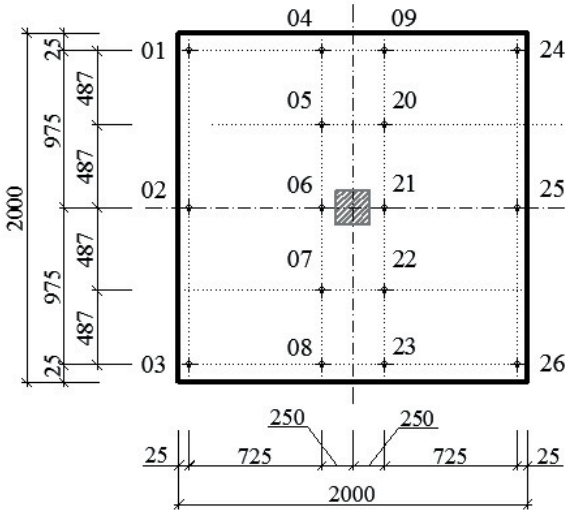

G04_21.9.2016

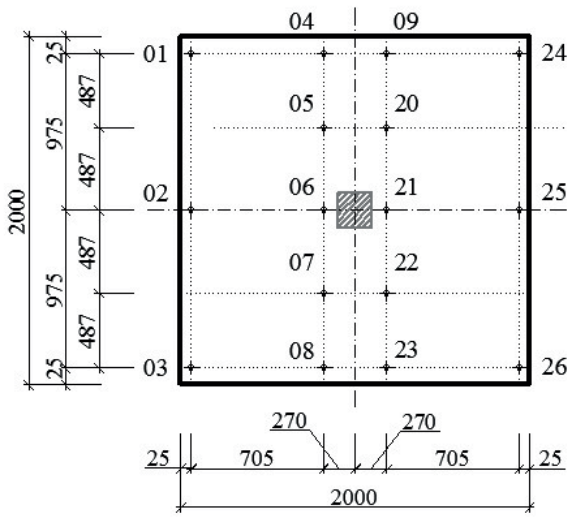

Fig. 15 Location of the track sensors in reinforced concrete slabs

The cracks can be located well, they have a vertical direction, and gradually open. Also, a typical phenomenon can be noted of the edges of the slab lifting. The resulting graphs for slab G01 of the loading course are shown in Fig. 16. The evaluation of the deformation by the individual track sensors is shown in Fig. 17. Another significant change in the behaviour of the slab during loading happens at the load of $248 \mathrm{kN}$ after 5 hours and $30 \mathrm{~min}-$ utes. In this loading step, there is a significant localization of concrete failure during load spreading over the slab.

A compression forming of the concrete occurs. The maximum stable load is $296 \mathrm{kN}$. Subsequently, the test was terminated. Upon further investigation of the damaged slab it was found that there was a significant compression forming of the slab. The disrupted area had an almost perpendicular shape.

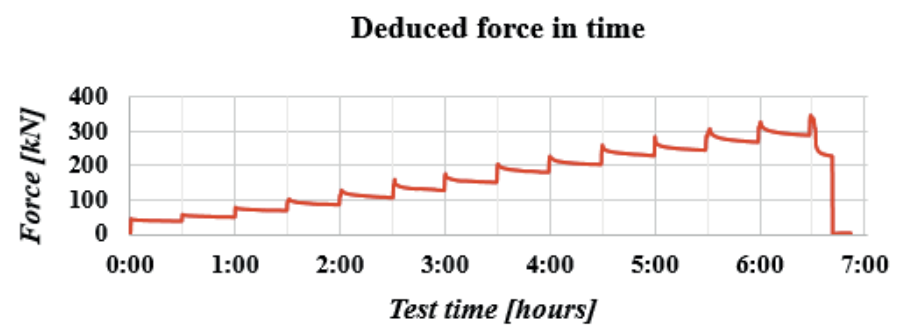

Fig. 16 Loading curve - slab G01

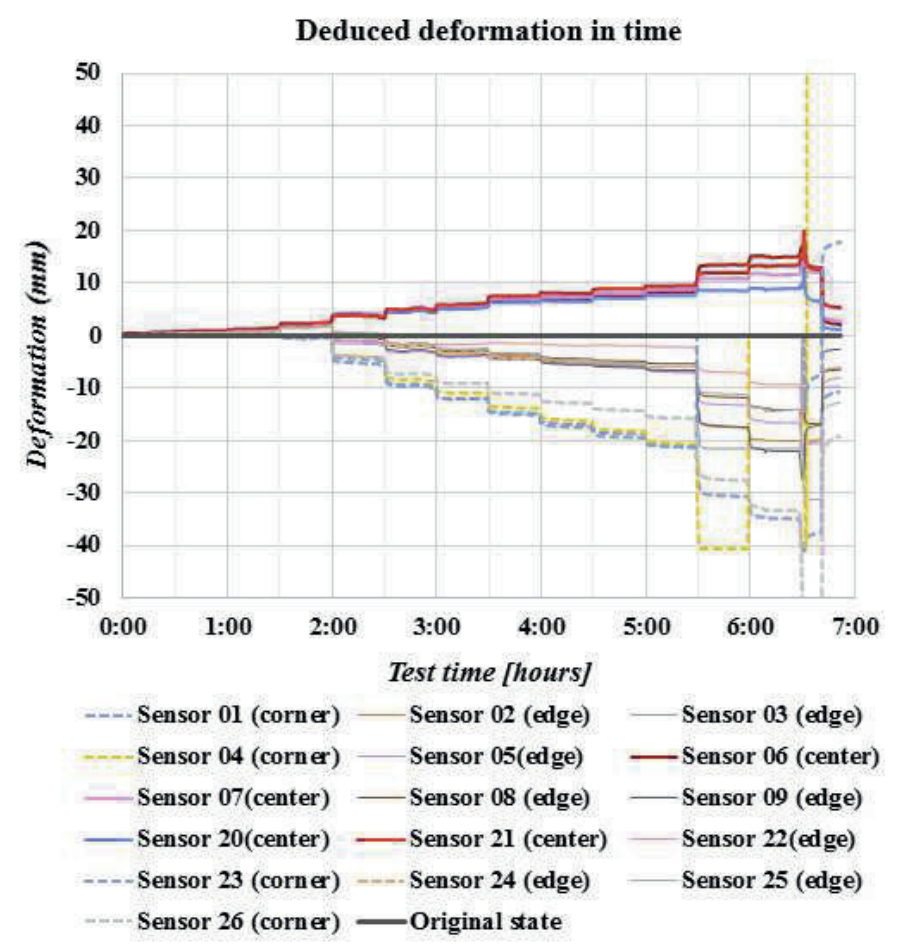

Fig. 17 Deformation curve during loading - slab G01

The following load tests were performed with steel fibrereinforced concrete. The second slab G02 was made from concrete containing $25 \mathrm{~kg}$ of fibre per $\mathrm{m}^{3}$. The selected load step was again 30 minutes. The load increment was approximately 
$75 \mathrm{kN}$. In this case, a significant change in bending stiffness occurred at $138 \mathrm{kN}$. Cracks appeared again at the bottom under the load and gradually spread to the outer edge. The damage of the concrete slab is again localized in two and three dominant cracks on each side of the slab. These cracks gradually opened during further loading. The flexural rigidity of the slab decreased very slowly. Another significant change in the deformation and the bending stiffness of the slab occurred at the load of $398 \mathrm{kN}$. Subsequently, a compression forming of the slab occurred from one side and the test was terminated. The maximum stable load was $478 \mathrm{kN}$. The loading and deformation curves are shown in Fig. 18 and 19.

The following load tests were performed with a slab G03 made from concrete containing $50 \mathrm{~kg}$ of fibre per $\mathrm{m}^{3}$. The load step did not change. The load increment was again approximately $75 \mathrm{kN}$. A change in bending stiffness occurred at 140 $\mathrm{kN}$, as with the previous slab. This is in accordance with the laboratory results, since the transverse tensile strength of both steel fibre-reinforced concrete slabs was very similar.

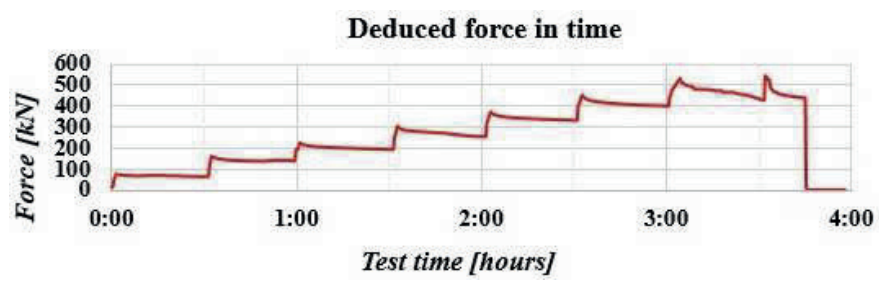

Fig. 18 Loading curve - slab G02

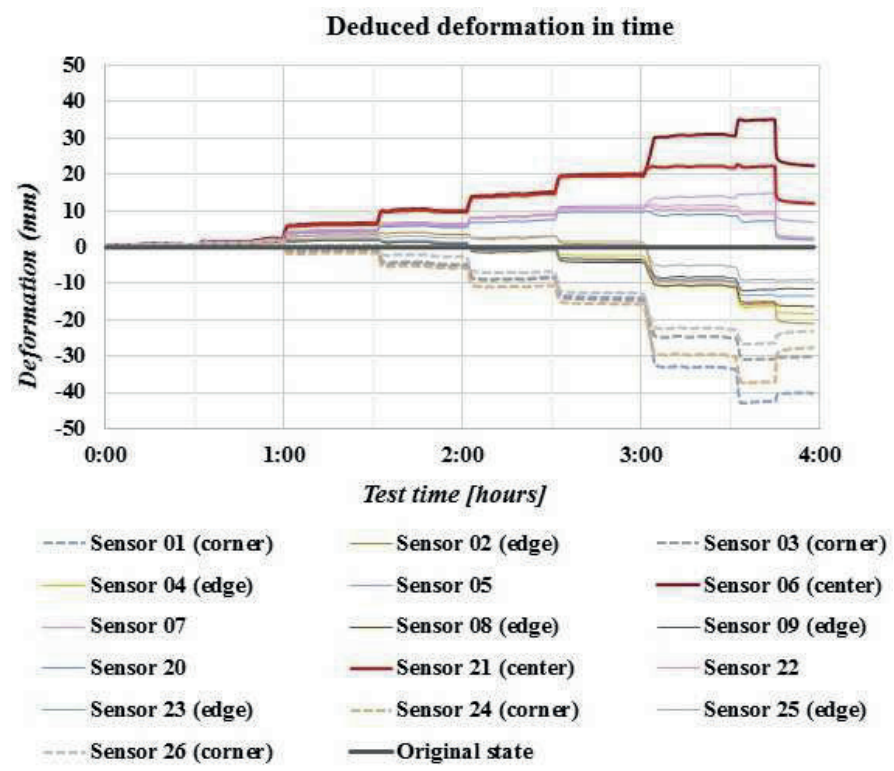

Fig. 19 Deformation curve during loading - slab G02

The damage was again localized in dominant cracks. They grew as the load increased. Another change in the bending stiffness of the slab occurs at $338 \mathrm{kN}$. The flexural rigidity of the slab begins to decline more significantly, there is also a significant opening of the formed cracks at the bottom surface and a vertical deformation. The load increases up to $550 \mathrm{kN}$.

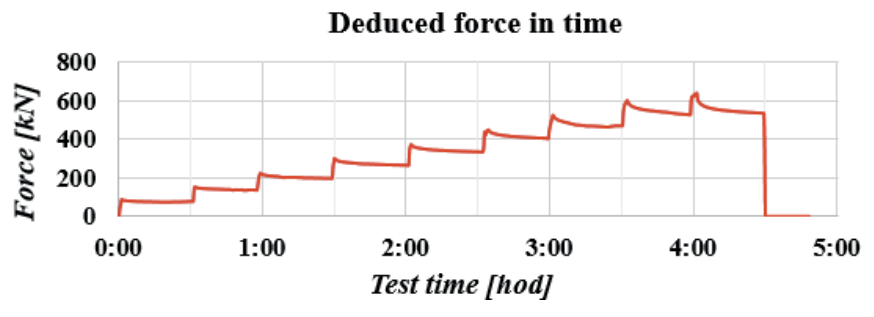

Fig. 20 Loading curve - slab G03
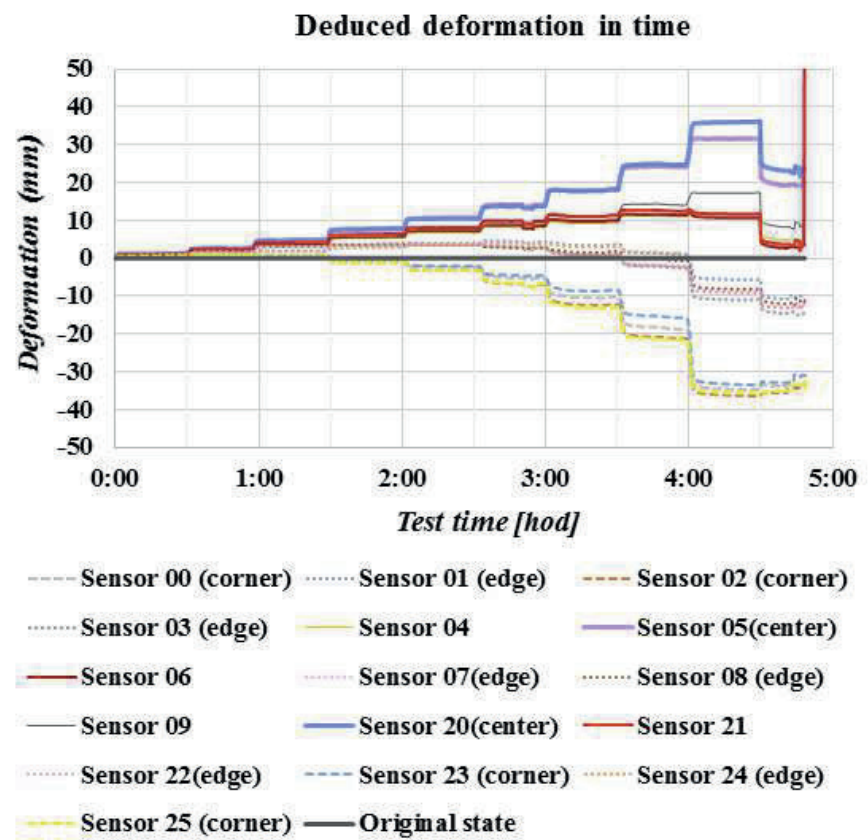

Fig. 21 Deformation curve during loading - slab G03

Vertical cracks which propagated from the bottom edge spread in the final phase of the load over the entire slab thickness. The collapse of the concrete slab occurred when a shear crack emerged, running from the load plate at an angle of $45-60^{\circ}$. The loading and deformation curves are shown in Fig. 20 and 21. The last slab G04 intended for the load test was made from concrete containing $75 \mathrm{~kg}$ of fibre per $\mathrm{m}^{3}$. The load step did not change and the load increment was $75 \mathrm{kN}$.

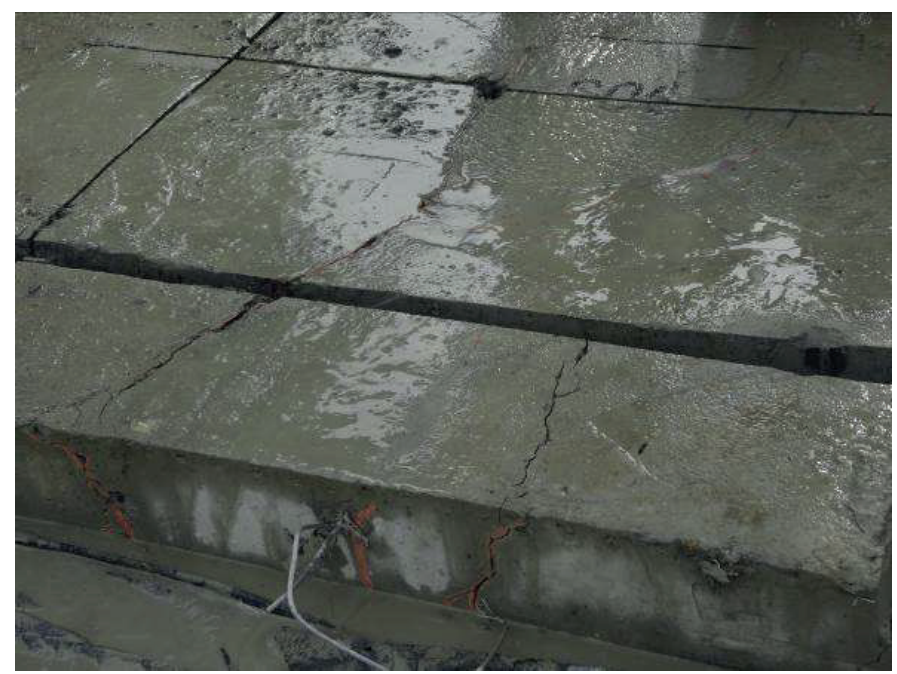

Fig. 22 Concrete edge slab G04 - Crack (Detail) 


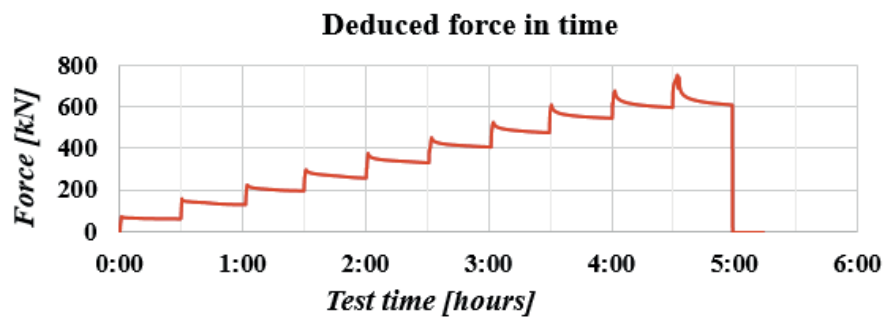

Fig. 23 Loading curve - slab G04

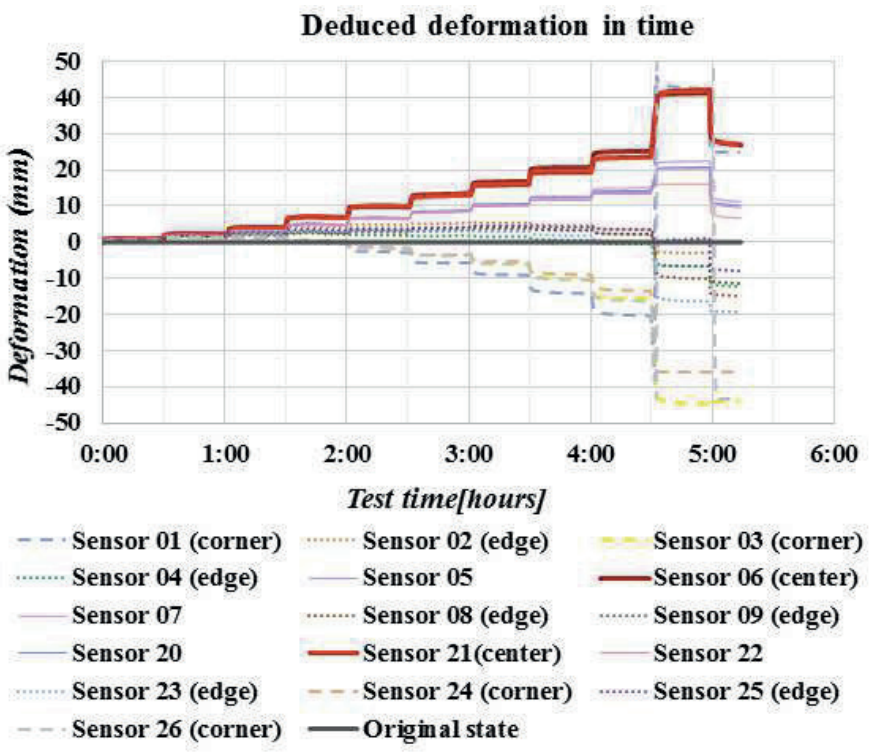

Fig. 24 Deformation curve during loading - slab G04

A significant change in bending stiffness occurred at the loading of $135 \mathrm{kN}$. Furthermore, the flexural rigidity of the slab gradually decreases with the increasing number of load steps. At a higher intensity of loading over $483 \mathrm{kN}$ a more significant formation and a propagation of cracks occurs. Cracks are already all over the whole thickness of the concrete slab. Cracks arise also on the upper surface near the load plate. The total bearing capacity is exhausted at $634 \mathrm{kN}$.

Furthermore, only the deformation grows bigger. Cracks at the edge of the plate show in Fig. 22. The concrete slab is broken by cracks and still remains compact. Upon completion of the test and the subsequent cutting of the slab into recess it was found that the cause of the collapse was a shear failure and the creation of the shear cone in the area around the load plate. The angle was approximately around $45 \%$. The loading and deformation curves are shown in Fig. 23 and 24. Cracks in the center slab show in Fig. 25.

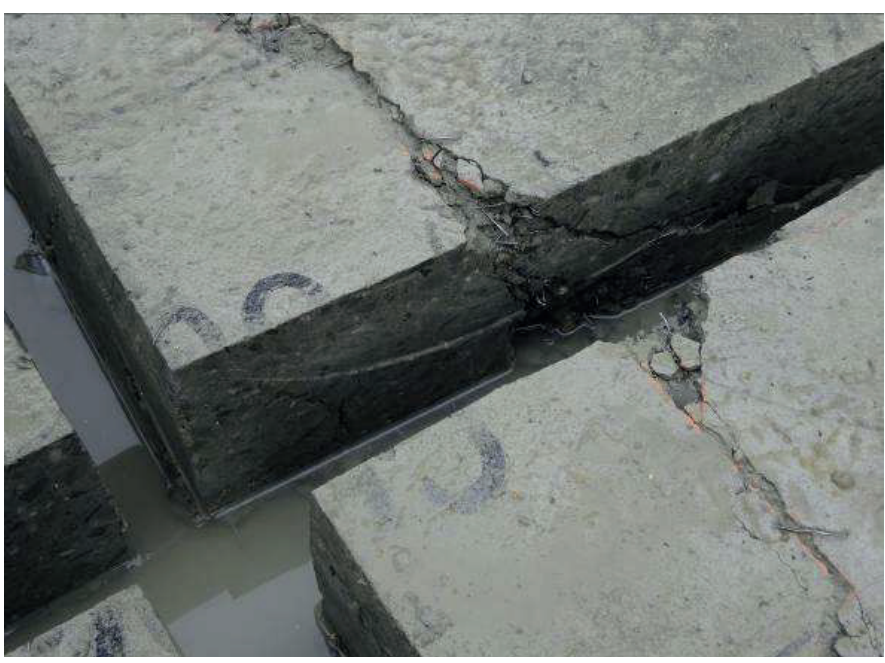

Fig. 25 Concrete center slab G04 - Crack (detail)

The resulting values of the slab bearing capacity are summarized in Table 14. The bearing capacity slab values are for steady state pressure. Table 14 includes also maximal peak loads and numerical results.

\section{Numerical modelling}

The experimental programme was followed by numerical modelling. The object of the numerical modelling was the concrete slab on site, for which the data from the laboratory tests was used for the input parameters of the concrete. The aim of the numerical modelling was to determine the total bearing capacity of the slabs, including the manner of failure and collapse.

3D computing models and nonlinear analysis were used for the numerical modelling. There are numerous approaches to the nonlinear analysis of concrete structures. In the case of steel fibre-reinforced concrete, two options are often used. The first approach is based on the fact that the effect of reinforcement fibres is taken into account directly in the concrete material model using input parameters. The second possibility is that the concrete and fibres are modelled separately. This approach is chosen for the following analyses. The approaches to modelling reinforcement are described in [36]. When selecting a constitutive model of concrete, the basic approaches to nonlinear analysis included in the Model Code 2010 [6] were taken into account. Specifically, a chosen constitutive model of the concrete is based on fracture-plastic theory. Specifically, the computing system ATENA [37] was used and the option 3D Non Linear Cementitious 2 [38] was chosen from the library. The 3D computing model itself covered all essential parts of the load test. 


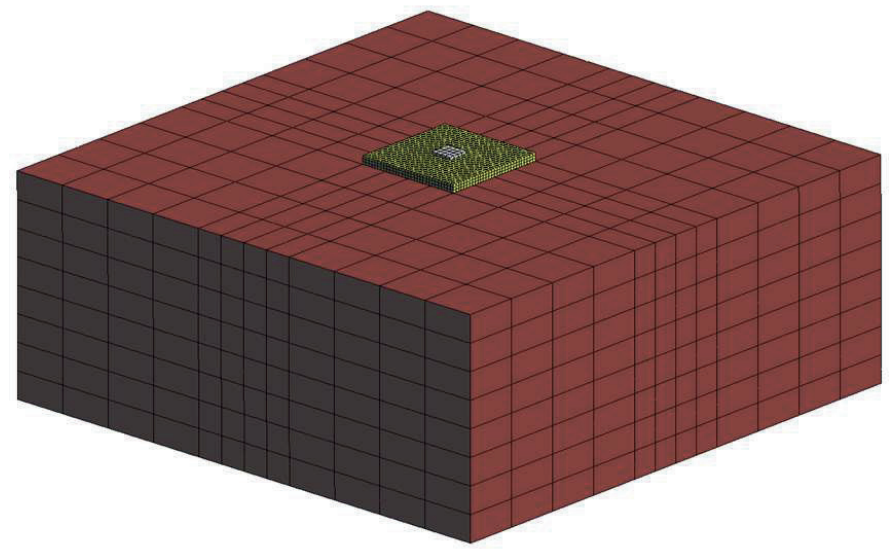

Fig. 26 Computing model - concrete slab + subsoil

This was a concrete slab, steel load plate and subsoil. The finite element mesh is regular shape and is formed with cubic finite elements. The regular mesh of finite elements is formed by a generator. Subsoil area size in the 3D computational model was $10 \mathrm{~m} \times 10 \mathrm{~m}$ and depth $4 \mathrm{~m}$. The size of the edge of the finite element is between from 0.25 to $0.5 \mathrm{~m}$. Basis value of soil elasticity module is mean value $E_{\text {def, } 1}$ and $E_{\text {def, } 2} .3 \mathrm{D}$ computing model consists of isoparametric finite element [37] with 8 integration points. Modelled subsoil has eight layers of finite elements. The size of solved area and 3D computing model was chosen based on previous calculations and computational requirements. The size of solved area affects the results deformation and bearing capacity of slab. Smaller effect is case bearing capacity of slab. Approaches for selecting parameters for a given task can be found in the article [39]. Single nonlinear analyses were counted 6-8 hours.

The finite element mesh is visible in the graphic chart in Fig. 26. The contact between the slab, subsoil and distribution plate was firm. To solve the nonlinear equation system the NewtonRaphson method was chosen. The load was induced by the deformation. The task can be solved symmetrically. The 3D computing models were however used.

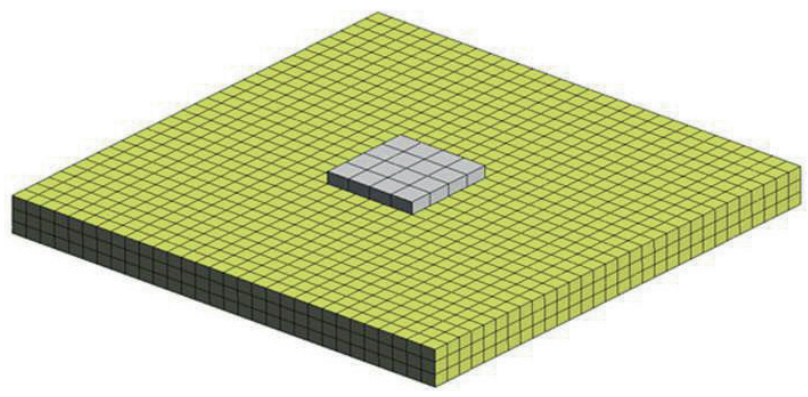

Fig. 27 Computing model - concrete slab (detail)

The calculation was also made for the 3D computing model. For the input parameters of the concrete model the following data from the laboratory tests was used: compressive strength, transverse tensile strength and the fracture energy of the threepoint bending test with a notched beam. Determining the input parameters was based on the recommendations in [37]. For fibres, the model of the spread reinforcement and the input parameters listed in Table 1 were used. The visualization concrete slab of the calculation model is shown in Fig. 27.

The calculation itself included four variants according to the reinforcement of the slab. The resulting values of the total bearing capacity for the individual variants are presented in Table 14.

In Fig. 28, 29 and 30, it is possible to see the development of cracks or stress in the selected slab model G01 and G03. The resulting development curve of cracks and the final collapse correspond to the actual behaviour of the concrete slabs.

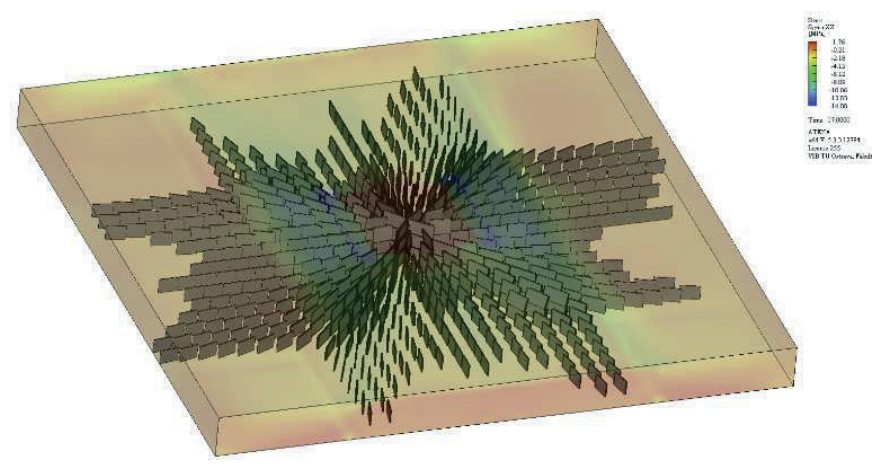

Fig. 28 Grafical results - crack + stress $\sigma_{x}($ slab G01)

\section{Summary of results}

The presented experimental programme provides a comprehensive set of laboratory tests and load tests of the actual concrete slabs. In the case of the chosen variant of steel fibrereinforced concrete, the positive effect is already evident in the basic types of laboratory tests. Typically, it is the determination of compressive strength and transverse tensile strength.
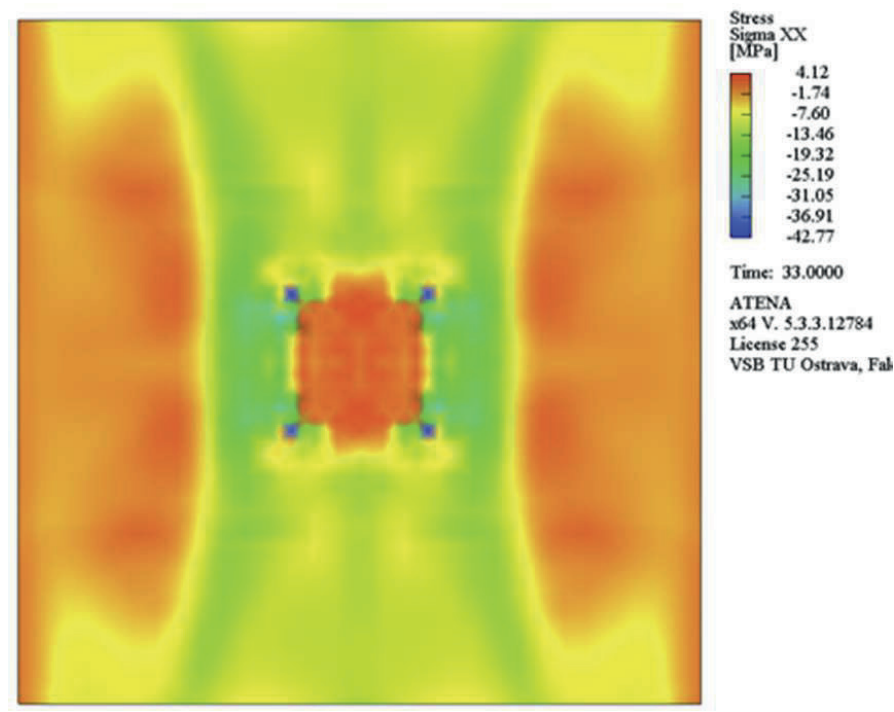

Fig. 29 Grafical results - stress $\sigma_{x}($ slab G03)

However, the possibility to determine the relationship between the degree of reinforcement and compressive strength is limited. This requires a broader set of samples and additional information. The compressive strength is also very sensitive to the position and orientation of the fibres. 
From the evaluated pressure tests it is possible to state that the same relations as for plain concrete can be used to convert the cubic and cylindrical strength. In the sample test this was specifically 0.83 . The increase in compressive strength in concrete with the fibres is in the range few percent.

In the case of the test in the transverse strength the properties improved typically by about up to $50 \%$, i.e. from $2 \mathrm{MPa}$ to $3 \mathrm{MPa}$. The differences between the results of reinforced samples were small, however. This corresponds well with the concrete slab testing where the first cracks, affecting the bending stiffness of slabs, typically occurred at about $140 \mathrm{kN}$. Tests in transverse tensile strength do not provide a detailed description of the further behaviour of damaged concrete. For this purpose a number of three-point and four-point bending tests were used. Four variants, which are the most commonly used, were selected within the experimental programme. This enabled a broader view when evaluating and setting the basic ratios between tests. The detailed results are shown in Table 14.

Table 14 Bearing capacity of concrete slabs

\begin{tabular}{lccccc}
\hline $\begin{array}{l}\text { Slab } \\
\text { number } \\
\left(\text { fibre kg/m }{ }^{3}\right)\end{array}$ & $\begin{array}{c}\text { Load Peak } \\
\text { Exp. }[\mathrm{kN}]\end{array}$ & $\begin{array}{c}\text { Load Max. } \\
\text { Exp. }[\mathrm{kN}]\end{array}$ & $\begin{array}{c}\text { Bearing } \\
\text { capacity } \\
\text { increased } \\
{[\mathrm{kN}]}\end{array}$ & $\begin{array}{c}\text { Calc. } \\
{[\mathrm{kN}]}\end{array}$ & $\begin{array}{c}\text { Exp. Load } \\
\text { Max./Calc. }\end{array}$ \\
\hline G01 (0) & 345 & 296 & - & 265 & 1.12 \\
G02 (25) & 542 & 478 & 182 & 456 & 1.05 \\
G03 (50) & 640 & 550 & 286 & 561 & 0.98 \\
G04 (75) & 752 & 634 & 338 & 621 & 1.02 \\
\hline
\end{tabular}

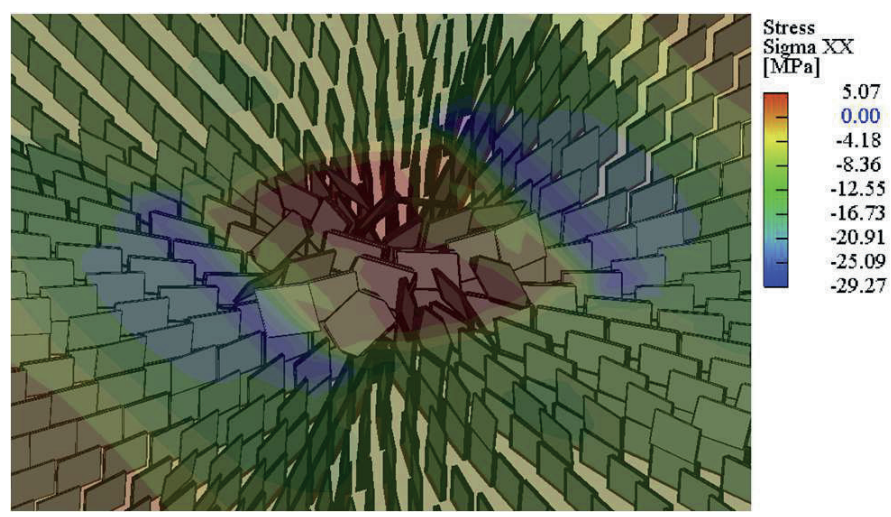

Fig. 30 Grafical results - crack + stress $\sigma_{x}($ slab G03)

The most important material properties which are necessary for a more detailed numerical modelling of steel fibre-reinforced concrete structures include the determination of fracture energy from the LD diagrams. Given the potential of the test equipment an evaluation for the deformation of up to $5 \mathrm{~mm}$ and $8 \mathrm{~mm}$ was conducted. The deformation of $5 \mathrm{~mm}$, for example, is set in recommendation TDM162 [8].

For the sake of completeness, the ratio of the fracture energy was also determined. Here is the typical ratio from 1.3 to 1.5 . To determine the maximum load and fracture energy it is possible to use very well established regressive curves.
In the load testing of concrete slabs, the influence of fibres on the overall bearing capacity and the manner of failure was clearly demonstrated. The most important influence on the slab bearing capacity was shown after adding $25 \mathrm{~kg}$ of fibres per $\mathrm{m} 3$. The bearing capacity increased by $61 \%(182 \mathrm{kN})$. In other cases of fibre-reinforced slabs is increase of bearing capacity smaller. The bearing capacity increases by $86 \%(286 \mathrm{kN})$ for concrete slab with $50 \mathrm{~kg}$ of fibres per $\mathrm{m}^{3}$ and $114 \%(338 \mathrm{kN})$ for concrete slab with $75 \mathrm{~kg}$ of fibres per $\mathrm{m}^{3}$. However, fibres have a significant influence on the ability to transform and maintain compact even damaged concrete.

\section{Conclusions}

The research presents the results of a comprehensive series of laboratory tests and tests on real concrete slabs. The object of the research is to evaluate the possibility of using steel fibrereinforced concrete slabs on the ground and to determine the material properties of concrete, depending on the degree of reinforcement. This experimental programme is also complemented by a numerical modelling of concrete slabs with the input parameters of concrete use data from laboratory tests. The set of laboratory tests makes possible a complete viewpoint of the material properties which may be used in the cases of advanced modelling and nonlinear analysis of concrete structures. Overall, the laboratory tests involved eight variants.

New knowledge about the properties of the material can be used or applied to similar tasks, especially in the case of the nonlinear analysis of concrete structures. These findings could be further developed as follows:

- The actual effect of fibre concrete reinforcement on compressive strength of the selected concrete mix and the type of wire is in the range of only a few percent. The results of the compressive strength are significantly affected by the position and orientation of the fibres. For the conversion of cubic and cylindrical strength the relationship for plain concrete can be used.

- In the case of the transverse tensile strength the fibre reinforcement influence on concrete is significant. The transverse tensile strength is typically increased at all degrees of reinforcement by around $50 \%$.

- For a more comprehensive description of the material properties of steel fibre-reinforced concrete, it is necessary to use a three-point and four-point bending test. With these tests it is subsequently possible to determine the detailed description of the material properties. These include tensile and flexure fracture energy.

- In bending tests, regression trend lines are introduced for the maximum load and fracture energy depending on the degree of reinforcement. Determined regression curves correlate very well with the measured data.

- A more complete description of this composite is very suitable for the design and analysis of a modern progressive design which uses nonlinear analysis. 
- Numerical models allowed a simulation of the actual damage of the structure and the determination of the total bearing capacity.

\section{Acknowledgement}

This outcome has been achieved with the financial support of the project GACR No. 16-08937S "State of stress and strain of fibre reinforced composites in interaction with the soil environment". In this undertaking, theoretical results gained by the project of "The conceptual research and development 2016" at the Faculty of Civil Engineering, VŠB - Technical University of Ostrava were partially exploited.

\section{References}

[1] Brandt, A.M. "Fiber reinforced cement-based (FRC) composites after over 40 years of development in building and civil engineering". Composite Structures, 86(1-3). pp. 3-9. 2008. https://doi.org/10.1016/j.compstruct.2008.03.006

[2] Karatas, M., Gunes, A. "Engineering Properties of Self-Compacting Concrete Produced by Polypropylene and Steel Fiber". Periodica Polytechnica Civil Engineering, 59(2). pp. 95-102. 2015. https://oi. org/10.3311/PPci.7348

[3] Németh, O., Lublóy, É., Farkas, G. "Bond of reinforcement in polymer concrete". Periodica Polytechnica Civil Engineering, 58(2). pp. 137-141. 2014. https://doi.org/10.3311/PPci.7502

[4] RILEM (2011): About Rilem [Online], http://www.rilem.net/gene/main. php?base $=500178$ [Accessed on 4 May 2011].

[5] DAfStbguidelines, 2011: DAfStb-Richtlinie Stahlfaserbeton. Deutscher Ausschuss für Stahlbeton - DAfStb, Berlin, German. (In German).

[6] Model Code 2010 - Final Draft, fib, Bulletin No 65 and 66. 1-2. 2012.

[7] Ali, A., Iqbal, S., Holschemacher, K., Bier, T. A. "Effect of Fibers on Bond Performance of Lightweight Reinforced Concrete". Periodica Polytechnica Civil Engineering, 60(1). pp. 97-102. 2016. https://doi. org/10.3311/PPci.8080

[8] "RILEM TC 162-TDF : Test and Design Methods for Steel Fiber Reinforced Concrete - Design of Steel Fiber Reinforced Concrete Using the $\sigma$-w Method: Principles and Application". Materials and Structures/ Matériaux et Constructions, 35, pp. 262-267. 2002. http://www.rilem. org/images/publis/1337.pdf

[9] RILEM (2000): Test and Design Methods for Steel Fiber Reinforced Concrete: $\sigma-\varepsilon$ Design Method, (Chairlady L. Vadewalle). Materials and Structures, 33 (226), pp. 75-81. 2000.

[10] Rilem TC 162-TDF: Test and Design Methods for Steel Fiber Reinforced Concrete: Background and Experiences. In. Proceedings of the RILEM TC 162-TDF Workshop. (Schnütgen, B., Vandewalle, L. (Eds.)). p. 222. PRO 031, RILEM Publications S.A.R.L., Bagneaux. 2003.

[11] RILEM TC 162-TDF: "Test and design methods for steel fibre reinforced concrete. $\sigma-\varepsilon$-Design Method - Final Recommedation”. Materials and Structures/Matériaux et Constructions. 36(262), pp. 560-567. http:// www.rilem.org/images/publis/1507.pdf

[12] Kormaníková, E., Kotrasová, K. "Elastic mechanical properties of fibre reinforced composite materials". Chemicke Listy, 105(s7), pp. 758-762. 2011. http://w.chemicke-listy.cz/docs/full/2011_17_s758-s766.pdf

[13] Erdélyi, A. “The Toughness Of Steel Fiber Reinforced Concretes". Periodica Polytechnica Civil Engineering, 37(4). pp. 329-344. 1993.

[14] Sahin, Y., Köksal, F. "The influences of matrix and steel fibre tensile strengths on the fracture energy of high-strength concrete". Construction and Building Materials, 25(4), pp. 1801-1806. 2011. https://doi. org/10.1016/j.conbuildmat.2010.11.084
[15] Sarfarazi, V., Ghazvinian, A., Schubert, W., Nejati, H. R., Hadei, R. "A New Approach for Measurement of Tensile Strength of Concrete". Periodica Polytechnica Civil Engineering, 60(2).pp. 199-203. 2016 https:// doi.org/10.3311/PPci.8328

[16] Sucharda, O., Pajak, M., Ponikiewski, T., Konecny, P. "Identification of mechanical and fracture properties of self-compacting concrete beams with different types of steel fibres using inverse analysis". Construction and Building Materials, 138. pp. 263-275. 2017. https://oi.org/10.1016/j. conbuildmat.2017.01.077

[17] Hillerborg, A. "Analysis of fracture by means of the fictitious crack model, particularly for fibre reinforced concrete". International journal of cement composites, 2(4), pp. 177-184. 1980.

[18] EN 14651:2005. Test Method for Metallic Fiber Concrete - Measuring the Flexural Tensile Strength (Limit of Proportionality (LOP), Residual) CEN European Commit-439 Tee for Standardization 440, EN 14651:2005+A1:2007(E).

[19] Katzer, J., Domski, J., "Static and dynamic characteristics of fibre reinforced WCA concrete". In: Proceedings of the International Conference FIBRE CONCRETE. Prague, Czech Republic. Sep. 10-11. 2011. pp. 250-259.

[20] Bažant, Z. P., Becq-Giraudon, E. "Statistical prediction of fracture parameters of concrete and implications for choice of testing standard". Cement and Concrete Research, 32(4), pp. 529-556. 2002. https://doi. org/10.1016/S0008-8846(01)00723-2

[21] Alani, A.M., Beckett, D. "Mechanical properties of a large scale synthetic fibre reinforced concrete ground slab". Construction and Building Materials. 41, pp. 335-344. 2013. https://doi.org/10.1016/j.conbuildmat.2012.11.043

[22] Karihaloo, B. "Fracture Mechanics of Concrete". Long-man Scientific \& Technical New York, 1995. ISBN: 0-582-21582-X

[23] Bekaert. http://www.bekaert.com/en/products/construction/concretereinforcement

[24] Cajka, R., Krivy, V., Sekanina, D. "Design and development of a testing device for experimental measurements of foundation slabs on the subsoil". Transactions of the V̌̌B - Technical University of Ostrava, Civil Engineering Series, 11(1), pp. 1-5. 2011.

DOI: https://doi.org/10.2478/v10160-011-0002-2

[25] Mynarcik, P., Cajka, R. "Experimental testing of post-tensioned concrete industrial floor model - subsidence analysis". International Journal of Mechanics, 10, pp. 33-38. 2016. http://www.naun.org/main/NAUN/mechanics/2016/a122003-175.pdf

[26] Mohyla, M., Vojtasik, K., Hrubesova E., Stolarik, M., Pinka, M. "The optimalization of pressure cell installation via numerical simulation". In: 16th internationla multidisciplinary scientific Geoconference SGEM 2016: Book 1: Science and Technologies in Geology, Exploration and Mining. Sofia, Bulgaria: STEF92 Technology Ltd., 2016, pp. 1029-1036. https://doi.org/10.5593/SGEM2016/B11/S02.130

[27] Pająk M, Ponikiewski T. "Flexural behavior of self-compacting concrete reinforced with different types of steel fibres". Construction and Building Materials, 47(10).pp. 397-408.2013. https://doi.org/10.1016/j. conbuildmat.2013.05.072

[28] ČSN EN 12390-6 Testing hardened concrete - Part 6: Tensile splitting strength of test specimens, CNI, 2010.

[29] B. Akcay, M.A. Tasdemir, "Mechanical behavior and fibre dispersion of hybrid steel fibre reinforced self-compacting concrete". Construction and Building Materials, 28(1), pp. 287-293. 2012. https://doi. org/10.1016/j.conbuildmat.2011.08.044

[30] Kang, ST, Lee, Y, Park, YD, Kim, JK. “Tensile fracture properties of an ultra-high performance fiber reinforced concrete. (UHPFRC) with steel fiber". Composite Structures, 92(1), pp. 61-71. 2010. https://doi. org/10.1016/j.compstruct.2009.06.012 
[31] Şahin, A., Koksal, F. "The influences of matrix and steel fibre tensile strengths on the fracture energy of high-strength concrete". Construction and Building Materials, 25(4), pp. 1801-1806. 2011. https://doi. org/10.1016/j.conbuildmat.2010.11.084

[32] M.H.A. Beygi, M.T. Kazemi, I.M. Nikbin, J.V. Amiri, "The Effect of water to cement ratio on fracture parameters and brittleness of self-compacting concrete". Materials \& Design, 50, pp. 267-276. 2013. https:// doi.org/10.1016/j.matdes.2013.02.018

[33] RILEM FMT 89, "Size-effect method for determining fracture energy and process zone size of concrete". Mater.Struct., 23(6), pp. 461-465. 1990.

[34] RILEM FMC-50".Determination of the fracture energy of mortar and concrete by means of three point bend tests on notched beams". Mater. Struct., 18(4), pp. 287-290. 1985.

[35] EN 14651:2005+A1:2007(E). "Test method for metallic fibre concrete measuring the flexural tensile strength (limit of proportionality (LOP), residual)". CEN European Commit-439 tee for Standardization 440. 2007.
[36] Sucharda, O., Brozovsky, J. "Models for Reinforcement in Final Finite Element Analysis of Structures". Transactions of the V $\check{S} B$ - Technical University of Ostrava, Civil Engineering Series, 11(2),pp. 1-11. 2011. https://doi.org/10.2478/v10160-011-0032-9

[37] Cervenka, V., Jendele L., Cervenka, J. "ATENA Program documentation - Part 1: Theory”.Cervenka Consulting. Pratur. 2007.

[38] Cervenka, J., Papanikolaou, V. K. "Three dimensional combined fracture-plastic material model for concrete". International Journal of Plasticity, 24(12), pp. 2192-220. 2008. https://doi.org/10.1016/j.ijplas.2008.01.004

[39] Labudkova, J., Cajka, R., "Numerical modeling of the subsoil-structure interaction". Key Engineering Materials, 691, pp. 333-343. 2016. https:// doi.org/10.4028/www.scientific.net/KEM.691.333 